\title{
Preventive Measures to Reduce Transmissible Diseases in Islamic Law
}

\author{
Mohammed Sami Al-Duleimy*, Zahir Faisal Al-Esawi \\ Center for Strategic Studies, University of Anbar, Iraq \\ * moh.farhan@uoanbar.edu.iq
}

\begin{abstract}
KEYWORDS: $\quad$ Measures, Pandemic, Prevention, Infection, Epidemic.
\end{abstract}
\begin{abstract}
:
Islamic law is concerned with treating infectious diseases by preventing them and limiting their spread, and it has indicated that the primary responsibility rests with the individual, so it obliges him to do everything that would limit the transmission of these epidemics, and the state is also responsible for providing everything that would limit these diseases and prevent their spread Such as imposing quarantine and providing medical and health care to those who have been afflicted by God with these diseases, and there is no doubt that infectious diseases some of them lead to the death of those who are infected with them, as in the Corona pandemic, and it is known that self-preservation is one of the most important objectives of Islamic law. Therefore, preventive measures must be taken into account. It can prevent the transmission of diseases and stop their spread. The jurists and scholars must explain to people the matters of their religion and world so that some of them do not fall into what is forbidden according to Sharia, so that they will be sinned by ignorance and without knowledge. The importance and reasons for choosing this topic comes in light of the spread of epidemics from time to time, the last of which is the Corona pandemic that has spread and afflicted many Muslims and some of them are ignorant of the jurisprudential rulings related to these epidemics such as the rule of non-compliance with the quarantine and the ruling on the transmission of infection intentionally and ignorant, as well as preventive measures Islamic law that limits the spread of these epidemics. Among the results that we reached in our research is that we have proven the transmission of infection, and it is a constant occurrence in our Islamic history and there is no room for denying it, so it is not permissible to deliberately transmit the infectious disease to healthy people and it is one of the major sins that entails God's punishment in the hereafter and retribution in this world. Ignorance and negligence of wrongdoing without intending there is no sin on him in the hereafter, but he must guarantee what he destroys in this world, because Islamic law has taken a group of them: the dislike of blowing into a bowl, the prohibition of spitting on the ground, and the necessity of purification from the impurity of some animals such as dogs and pigs that transmit diseases to humans Preventing defecation and urination in public resources, and many measures that prevent the transmission of diseases and limit them.
\end{abstract}




\title{
الإجراءات الوقائية للحد من الأمراض الانتقالية في الشريعة الإسلامية
}

\author{
أ.د. محمد سامي الدليمي*، أ.م.د. ظاهر فيصل العيساوي \\ مركز الدراسات الاستراتيجية، جامعة الأنبار، العراق \\ *moh.farhan@uoanbar.edu.iq
}

الكلمات المفتاحية اجراءات، جائحة، وقاية، عدوى، وباء.

Crossref doi) https://doi.org/10.51345/.v32i4.398.g249

\section{ملخص البحث: - (مثت}

أهتمت الشريعة الإسلامية بعلاج الأمراض المعدية وذلك من خحلال الوقاية منها والحد من انتشارها وبينت بأن المسؤولية

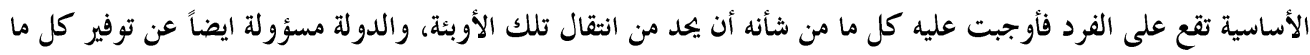

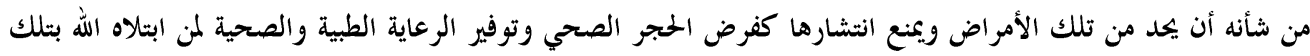

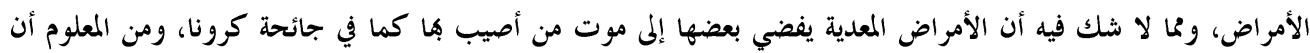

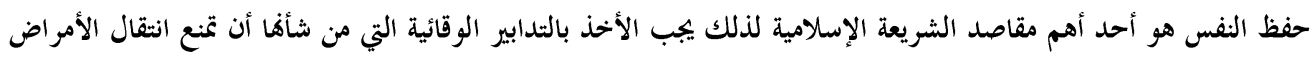

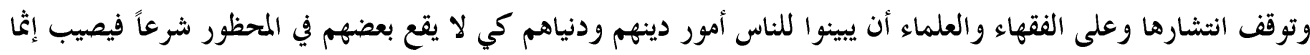

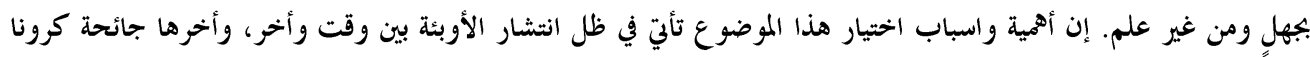

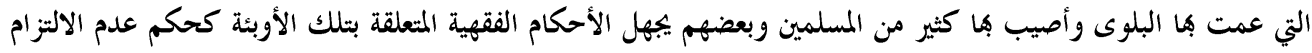

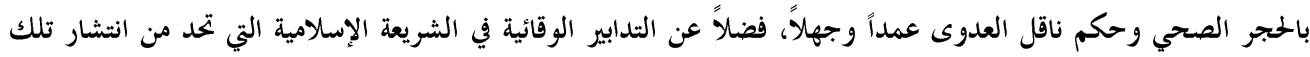

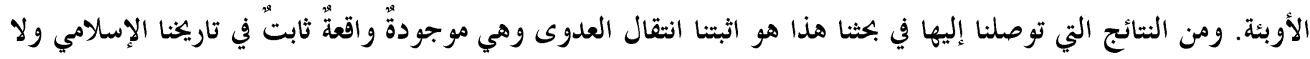

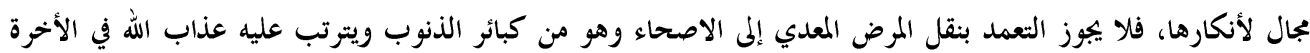

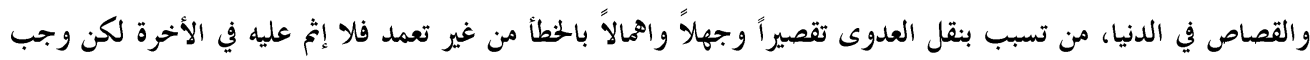

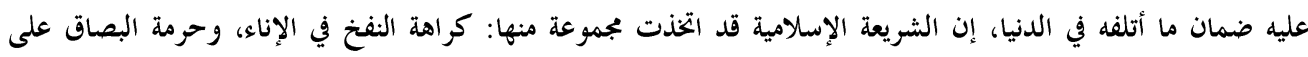

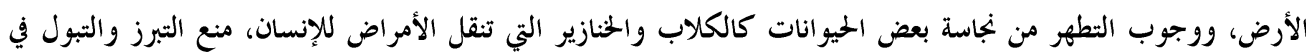

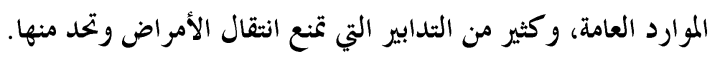

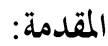

امتن الله جل في علاه على أمة الإسلام أن هداها لعبادته وجعل شريعتها خاتمة الشرائع تنتظم أحكامها

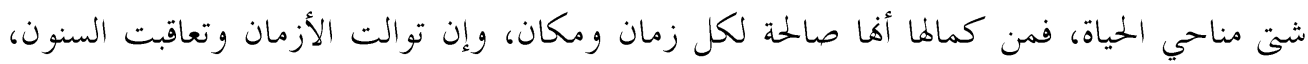
فالثبات و الجمود هو طابع الجمادات، أما التغير والتطور فهو ما تقتضيه الحياة البشرية التي لا يقر لها قرار 
ولا يهائ لها بال بغية تحقيق حياة أفضل للبشر، فكان لابد من حدوث أمور لم تكن قد حدثت من قبل كانتشار الأمر اض والأوبئة التي لها القدر على الانتشار والانتقال من شخص لألئ لأخر.

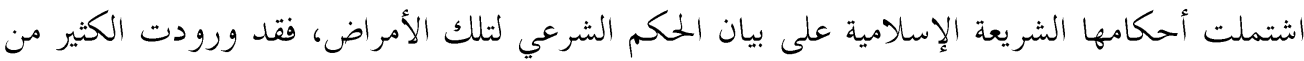
النصوص الشرعية التي تتحدث عن تلك الأمراض وتحد من انتشارها، فقد بين علماء الشريعة الآيات

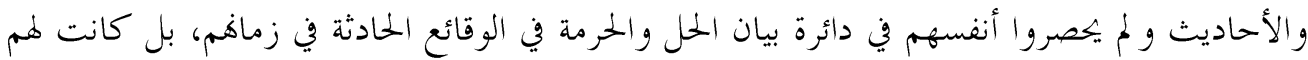

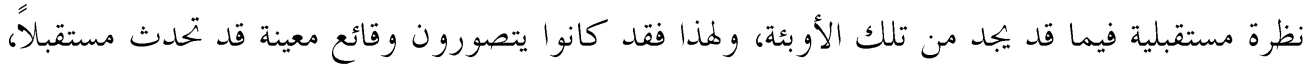

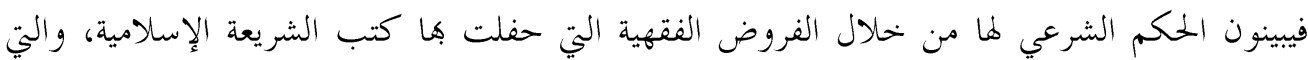

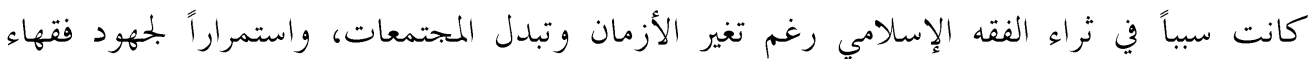
السلف واسهاماً منا لإثراء الفقه الإسلامي، اجتزأنا من بين القضايا المعاصرة قضية انتشار الأوبئة وتحديداً COVID 19 الذي ابتلينا به في بحتمعاتنا الإسلامية. إن الشريعة الإسلامية قد أهتمت بعلاج الأمراض المعدية قبل حدوثها وذلك من خلالال الوقاية منها والحد من انتشارها و بينت بأن المسؤولية الأساسية تقع على الفرد فأوجبت عليه كل ما من شأنه أن يحد

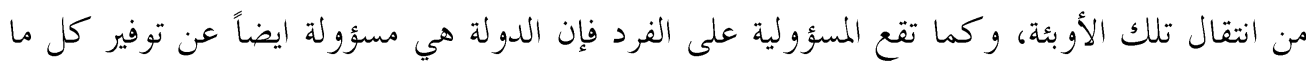

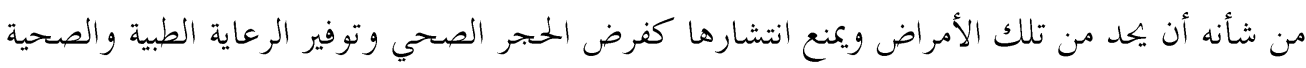

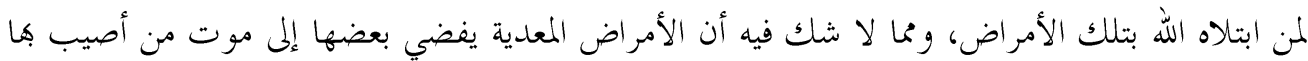

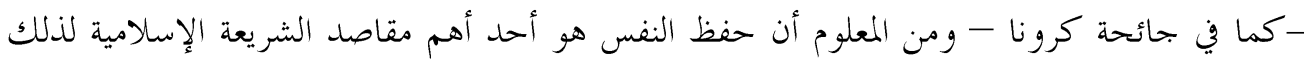
بيجب الأخذ بالتدابير الوقائية التي من شأها أن تمنع انتقال الأمراض وتوقف انتشارها وعلى الفقهاء والعلماء أن يبينوا للناس أمور دينهم ودنياهم كي لا يقع بعضهم في المحظور شرعاً فيصيب إثما بيجهلٍ ومن غير علم.

\section{أهمية وأسباب اختيار الموضوع}

1- يعد موضوع الأمراض المعدية وطرق انتقاها من أهم المواضيع المعاصرة في ظل انتشارها بين وقت وأخر، وأخرها جائحة كرونا التي عمت بها البلوى وأصيب بها كثير من المسلمين وبعضهم يجها منهل الأحكام الفقهية المتعلقة بتلك الأوبئة كحكم عدم الالتزام بالحجر الصحي وحهمى ناقل العدوى

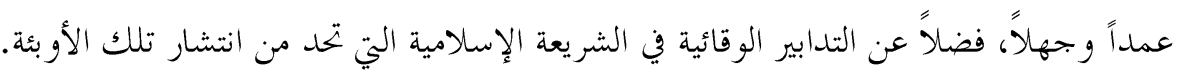


2- انتشار الأوبئة موضوع يهم كل فئات المجتمع، من علماء وقضاة وأطباء وغيرهم، وأهمهم الأطباء

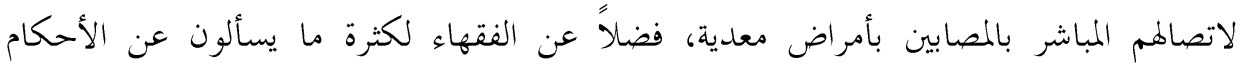
و القضايا في العبادات والجنايات التي تخص المصابين بالأمراض المعلدية.

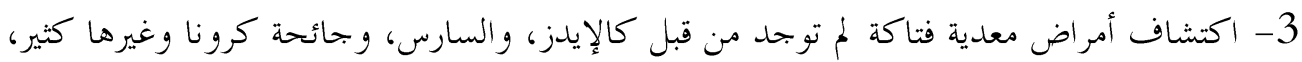

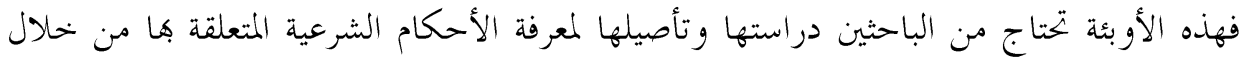
الأصول الشرعية والقواعد الفقهية المتعلقة بالمصاب هيا والمخالط له له.

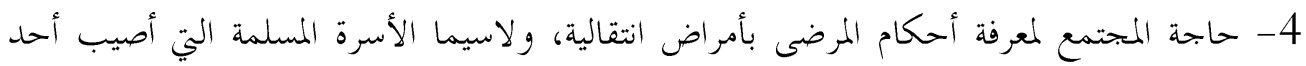
أفر ادها بتلك الأمراض، ومعرفة الأحكام الشرعية المترتبة على أفعالهم. 5- تعريف الأطباء بالأحكام التي يحتاجوها من المسائل الفقهية المتعلقة بالمصابين بأمر اض معدية.

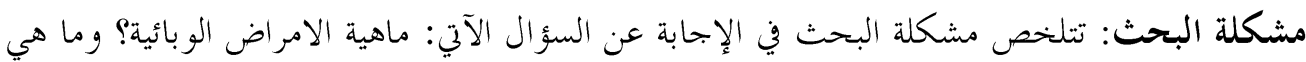
التدابير الوقائية الشرعية التي تحد من انتشارها؟ منهج البحث: تقوم طريقة البحث على المنهج الوصفي التحليلي الذي يستند إلى القرآن الكريم وسنة

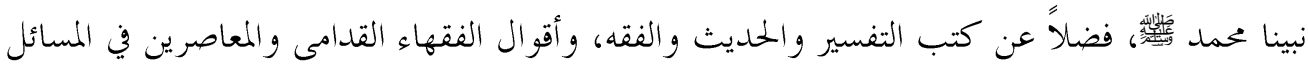
الاجتهادية والمحاثة، وبعض البحوث والدراسات الحلديثة المنشورة في المجلات العلمية وبحامع الفقه الإسلامي ذات الصلة ببحثنا، للاعتماد عليها للوصول إلى الأحكام والترجيحات الفقهية التي يتبناها بكثنا هذا مع بيان سبب الترجيح. حدود البحث: سنقتصر في بحثنا هذا على ذكر أقوال الفقهاء في المذاهب الأربعة المشهورة الأحناف،

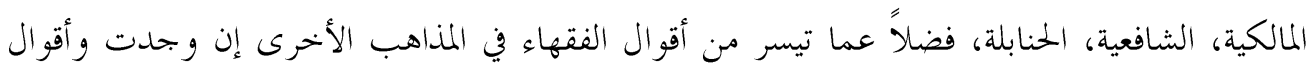
الفقهاء المتأخرين والأطباء.

\section{الدراسات السابقة}

أولاً: دراسة أبو حماد، أحكام نقل الأمراض المعدية دراسة فقهية، حسام حسن حسني أبو حماد، دراسة

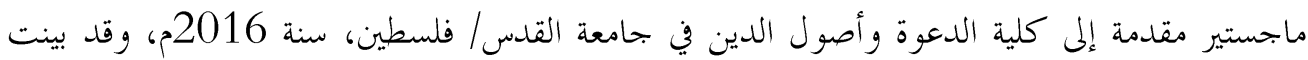
هذه الدراسة بعض الأحكام الفقهية لمن أصيب بمرض معدي. ومن تلك الأحكام: التفريق بين الزوجين بسبب مرض معدي، وحكم اجهاض الجنين للمصابة بمرض معدي، وحكم حضانة الطفل للمصابة كمرض معدي، وغيرها الكثير من الأحكام الفقيه في ثنايا تلك الرسالة. 
ثانياً: دراسة سعود، أحكام الأمراض المعدية في الفقه الإسلامي، عبد الإله بن سعود، رسالة ماجستير، ألمال،

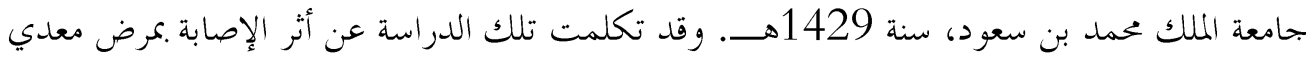
على العبادات. ومنها: تأثيرها في الصلاة والزواج والطلاق وغيرها من الأحكام الفقيه التي تؤثر في

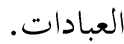

وما يميز دراستنا هذه عن غيرها أها تختص ببيان الإجراءات الوقائية في الشريعة الإسلامية التي منه شأها

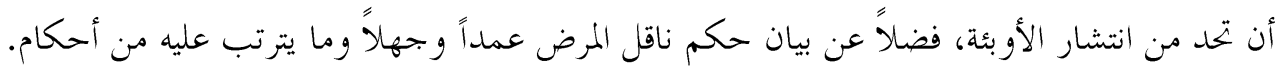

\section{المبحث الأول: التعريف بمصطلحات البحث}

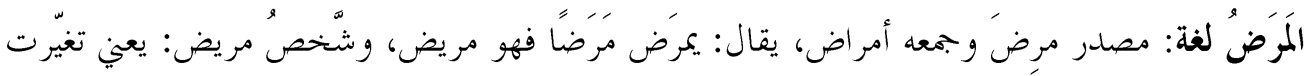

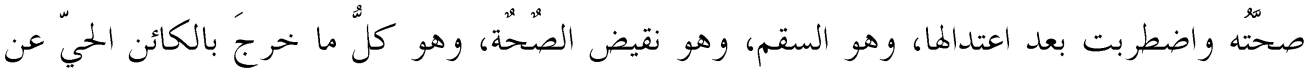

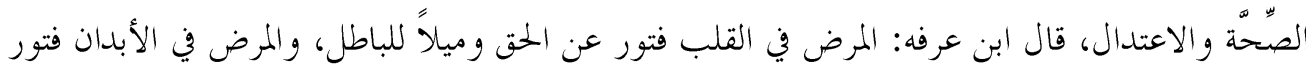
الأعضاء و اعتلالها(1).

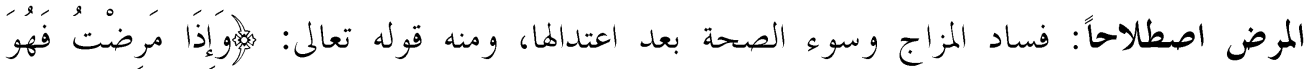

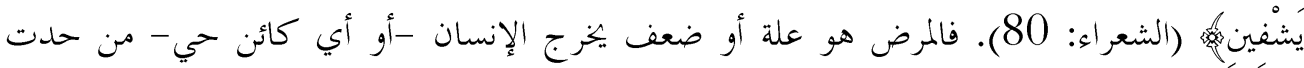
الاعتدال والصحة إلى السقم. مرض الموت: العلة المقعدة المتصلة بالموت(2).

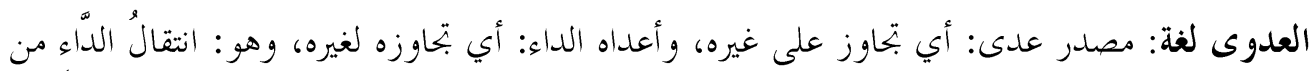

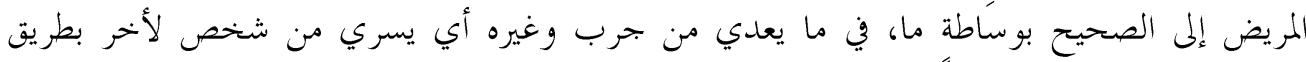
الآتصال المباشر أو غير المباشر (3).

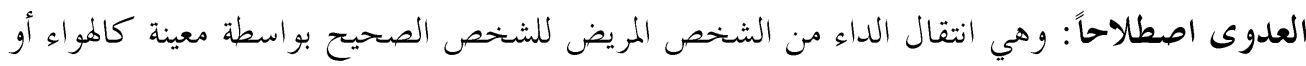

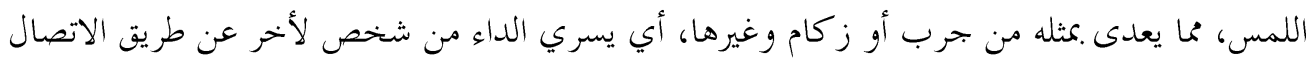

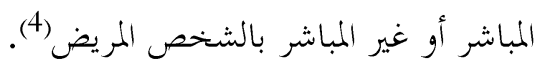

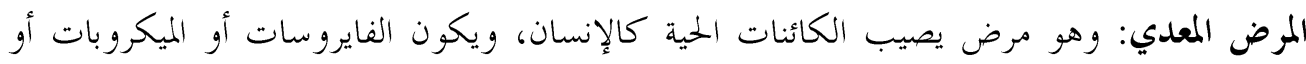
الطفيليات أو الفطريات هي المسبب للمرض، وله قابلية الانتقال من شخص لأخر بإحدى طرق العدوى، فمنها ما ينتقل بالتنفس كالز كام، ومنها ما ينتقل عن طرق الفم كالتيفوئيد ومنها ما ينتقل بالملامسة كالجدري، ومنها ما بتنقل عن طريق العلاقات الجنسية كالسيلان، وغيرها من الطرق

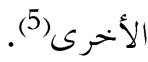


ناقل العَدْوَى: وهو الشخص أو الحيوان الذي لا تظهر عليه أعراض المرض لكنه يحمل الجُرْثْومة أو

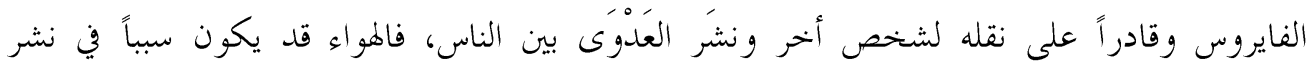

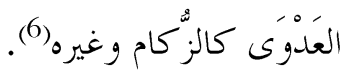

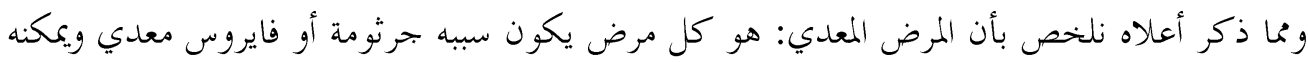

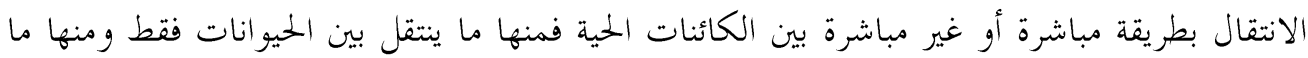

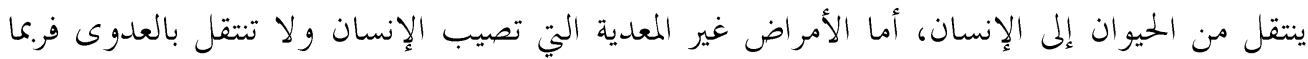

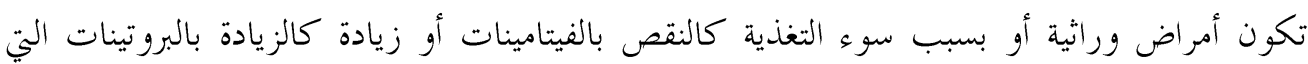

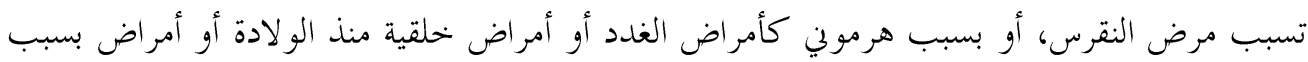
تكاثر وانشطار الخلايا الجسمية كالسرطان وغيرها كثير (7).

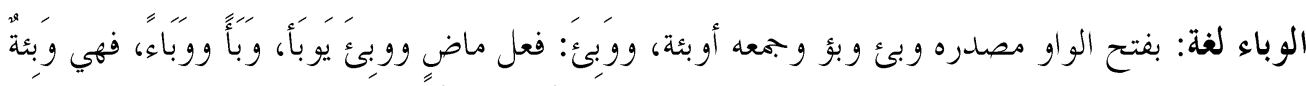

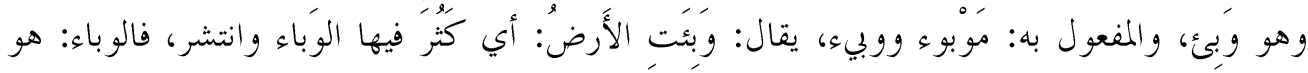

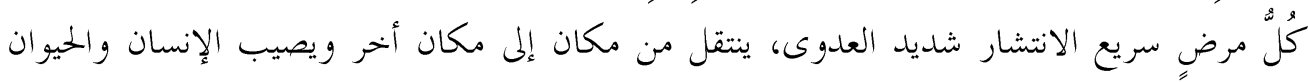

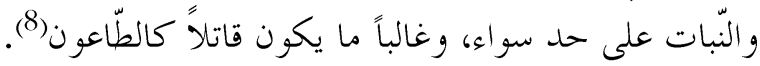
الوباء اصطلاحاً: لا يختلف تعريف الوباء في الاصطلاح عن تعريفه في المعنى اللغوي، ويكاد يتفق المعنى اللغوي مع المعنى الاصطلاحي فالوباء: هو فساد يعرض لجوهر الهواء لأسباب سماوية وأرضية(9). و وكثيراً

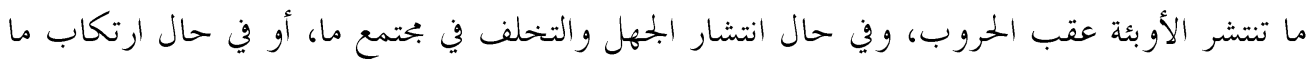

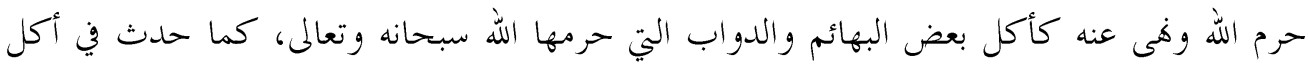
الأفاعي والخفافيش والكلاب، وهي المتهم الرئيسي بانتشار جائحة كرونا على مستى مستوى العالم.

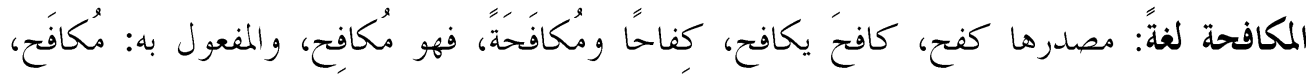

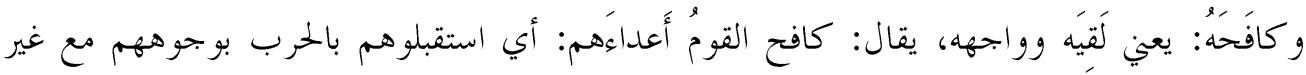

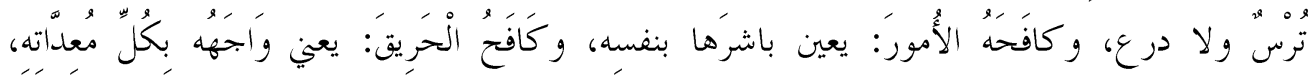

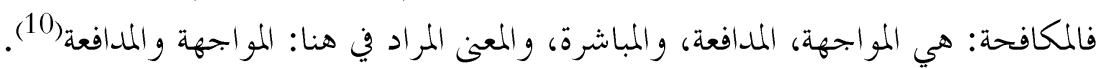

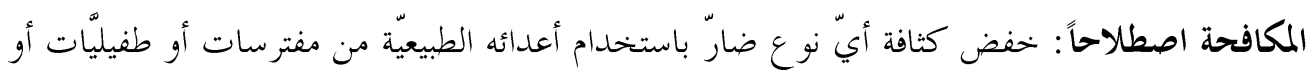
ميكرو بات(11). 


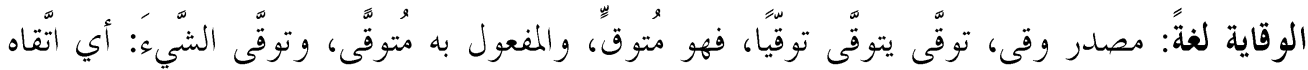

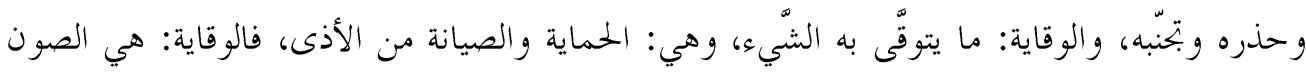

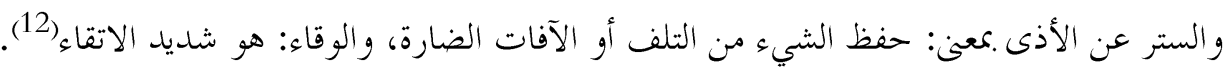

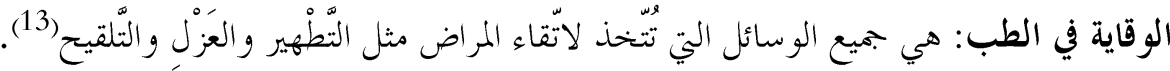

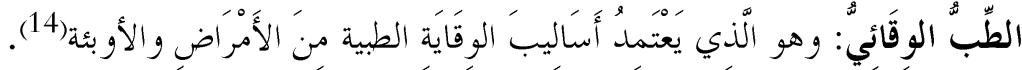

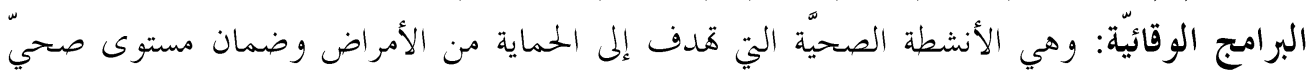
جيد، وذلك بالتطعيم والتوعية الصحية بالأمراض وأسباها وطرق انتقاها وكيفية الوقاية منها(15).

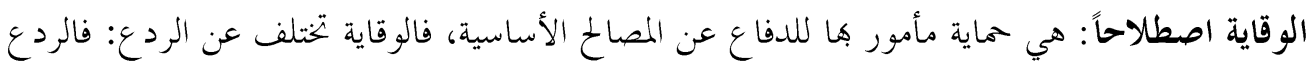

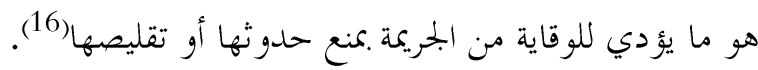
حقيقة الوقاية: هي بحموعة الاجراءات، والخدمات المنظمة والمقصودة التي تدف للحيلولة دون وقوع الخطر أو الإقلال من الأخطار - قدر الامكان(17).

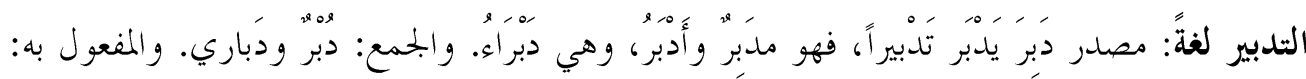

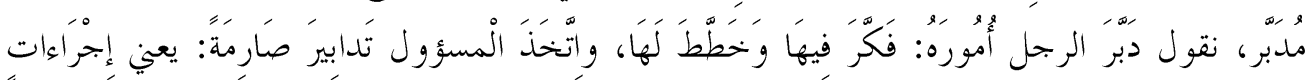

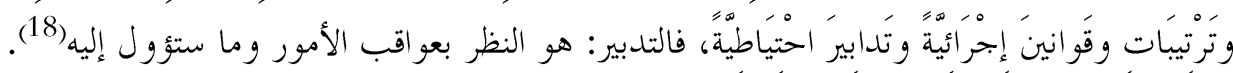

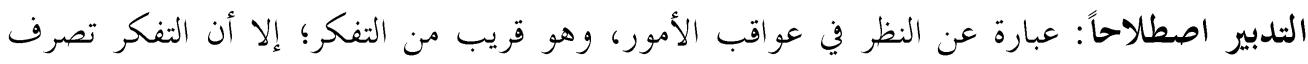

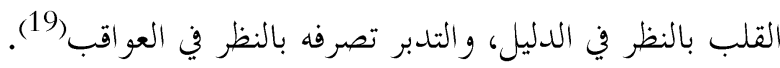

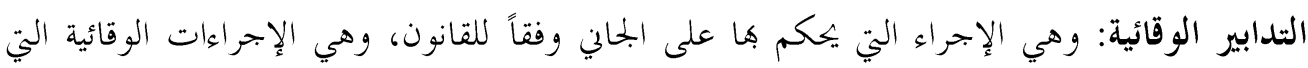
يقوم بها ذوي المهن الصحية للحد من الأمراض ومنع انتشارها(20).

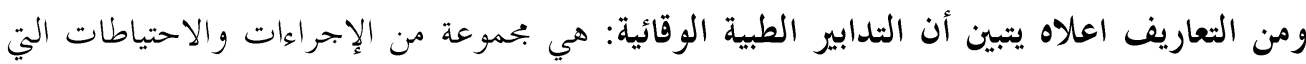

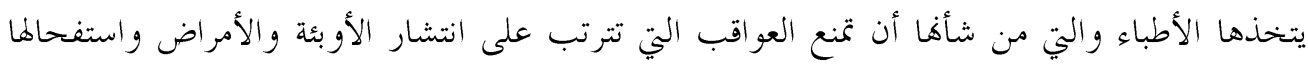
وعدم السيطرة عليها.

المبحث الثالي: أقوال الفقهاء في انتقال العدوى من عدمها وحكم انتقالها وفيه مطلبان: المطلب الأول: أقوال الفقهاء في انتقال العدوى من عدمها. المطلب الثاني: حكمم من الثمن تسبب بنقل العدوى. 


\section{المطلب الأول: أقوال الفقهاء في انتقال العدوى من عدمها}

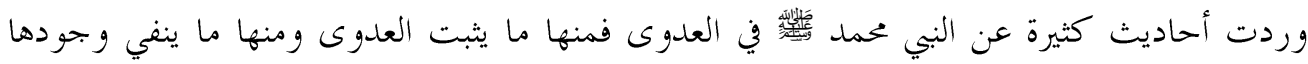
وهذا ما أوهم كثير من الفقهاء والمحدثين بقوهم بعلم وجود العلوى بناءً على أحاديث نفي العدوى من غير تبحر في المعنى المراد من الأحاديث والوقوف على دلالاها، ومراد البي محما، متوهين بوجود تعارض بين هذه الأحاديث، ومن النظرة الأولى للأحاديث وتفسيرها والوقوف على مدلو لاتًا و معرفة اسباهما يتبين لنا أن تلك الأحاديث بعيدة عن التعارض و التناقض، و من هنا فقد اختلف الفقهاء في اثبات العدوى و نفيها إلى قولين: القول الأول: القائلين بثبوت العدوى، وانتقالما إلى الغير عن طريق المخالطة كالمصافحة أو المعانقة أو نقل الدم وغيرها من الطرق الأخرى ولكنهم قالو إن المرض لا يتنقل بطبعه وإنما بأمر الله تعالى ومشيئه، وهو مذهب جمهور العلماء من الحنفية(21)، وهو القول المعتمد في الذهب المالكي (22)، والشافعية(23)، و الحنابلة(24)، و الظاهرية(25)، و الزيدية(26). القول الثالي: القائلين بعدم وجود العدوى، ونفي انتقاها، وإلى هذا القول ذهب كل من عيسى بن دينار، و أبن وهب(27) وبه قال الباقلاني، وأبن بطال، وقالو ا: بأنه لا عدوى إلا من الجذام فقط، و نفي ما دوهنا من انتقال الأمراض الأخرى عن طريق العدوى(28). أدلة أصحاب القول الأول: القائلين بثبوت العدوى يرى أصحاب هذا القول ثبوت العدوى وإن بعض الأمراض تنتقل عن طريق العدوى وهذا ما حدث

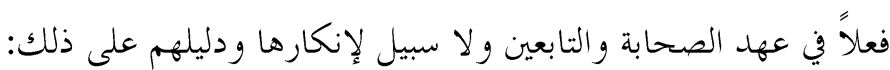

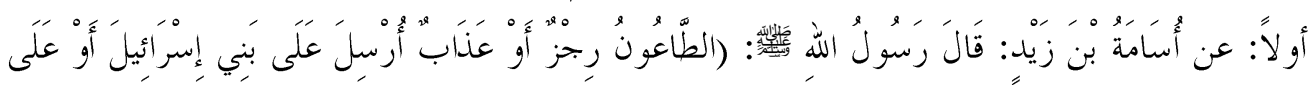

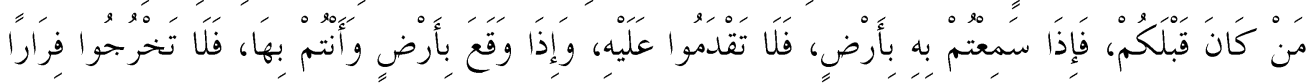
(29)( من (29)

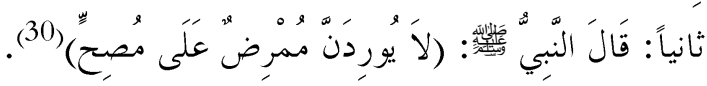

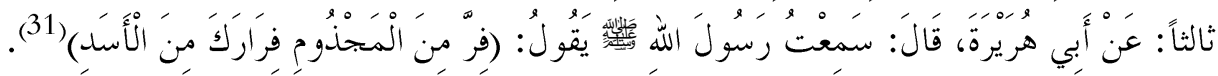

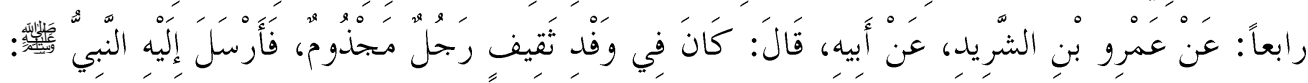

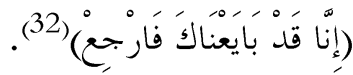

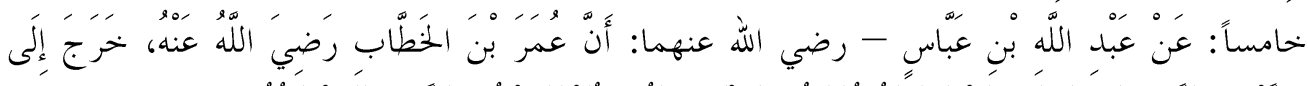

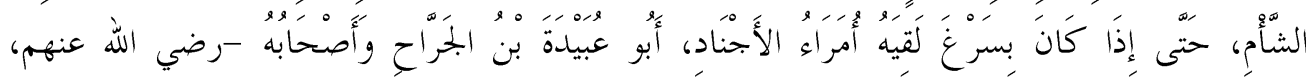




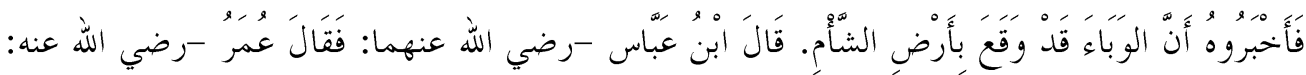

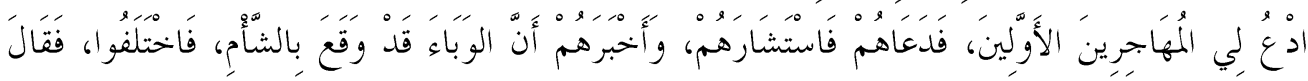

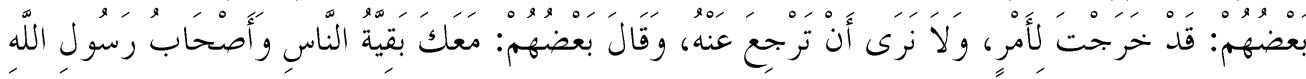

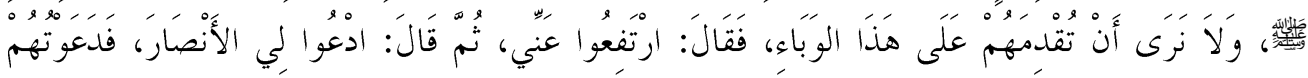

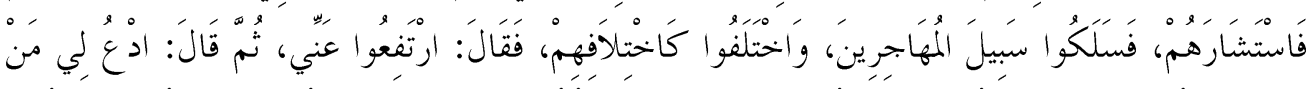

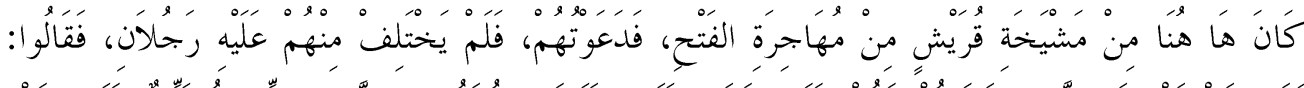

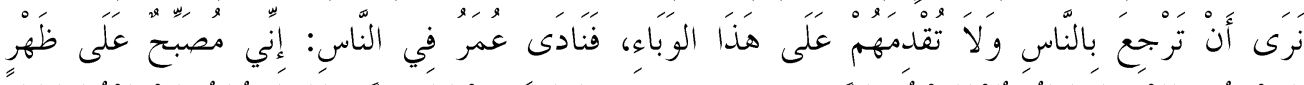

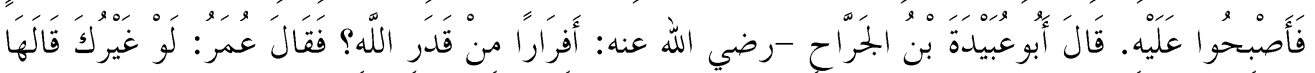

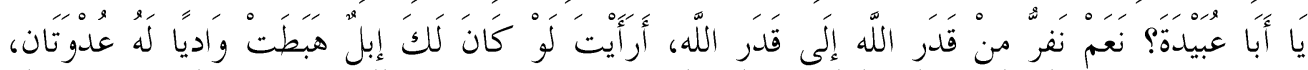

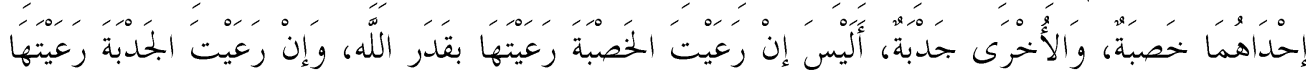

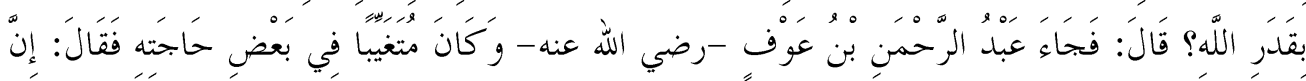

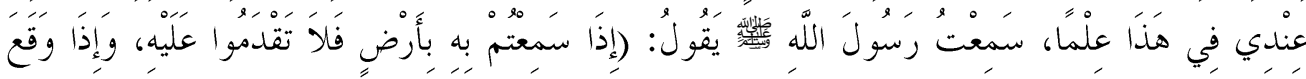

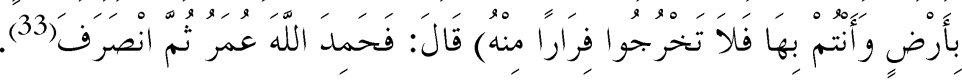

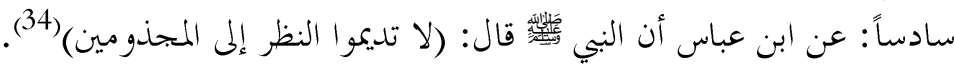

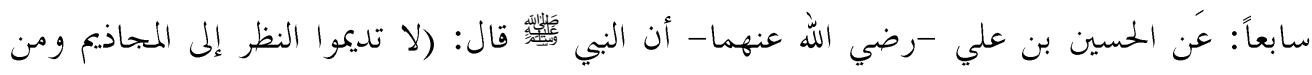
كلمه منكم فليكلمه و بينه و بينه قيد رمح)(35). و جحه الدلالة: دلت الأحاديث النبوية الشريفة على ثبوت العدوى وعلى ثبوت انتقالها من خلال الإقدام

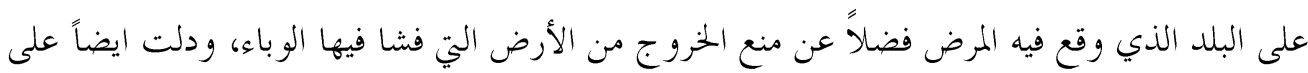
وجوب أخذ الحذر والاحتياط من الأمراض المعدية ووجوب الأخذ بالأسباب التي تمنع انتشار الوباء

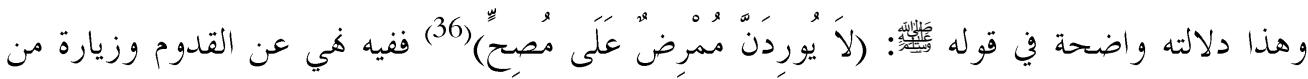
ابتلاه الله سبحانه وتعالى .كرض معد أي كان ذلك المرض، وهيه

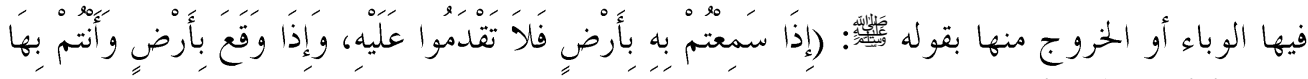

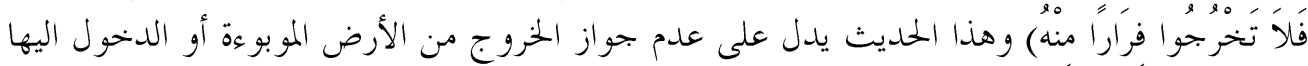
لكي لا ينتشر الوباء. أدلة أصحاب القول الثاني: القائلين بعدم بثبوت العدوى 
يرى أصحاب هذا القول بعدم ثبوت العدوى وإن الأمراض لا تنتقل عن طريق العدوى مستدلين عليه

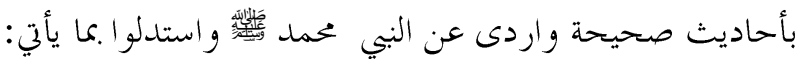

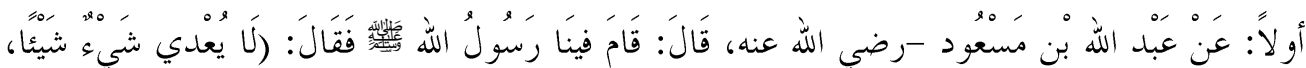

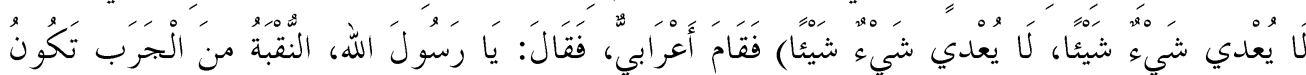

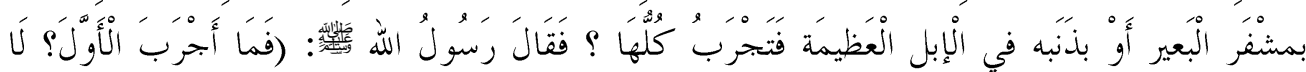

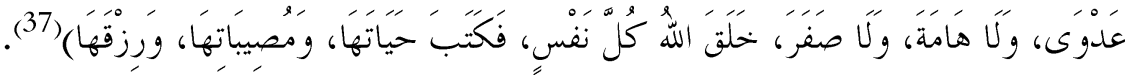

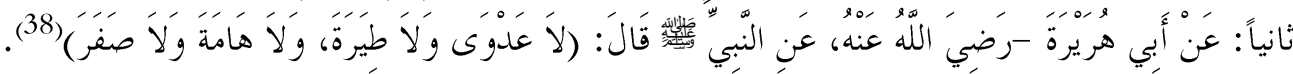

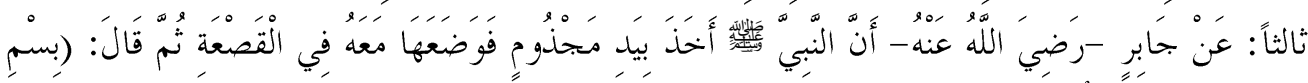

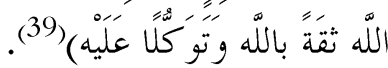
وجهه الدلالة: دلت الأحاديث النبوية الشريفة على عدم وجود العدوى ومنع انتقاهلها من شخص لأخر

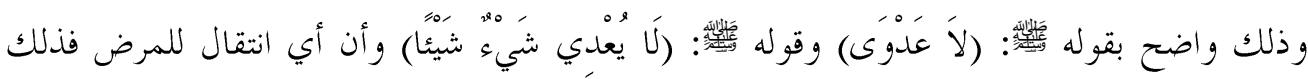
بأمر الله سبحانه وتعالى وليس بسبب العدوى وله وغيرها.

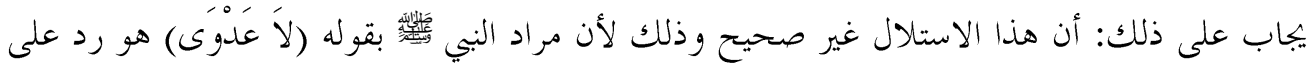

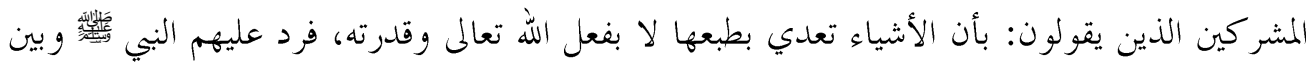

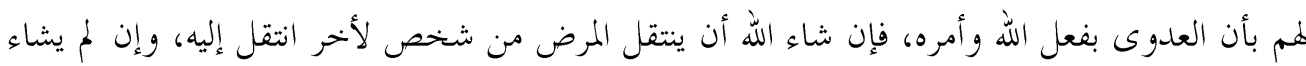

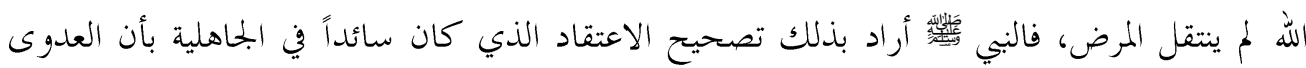

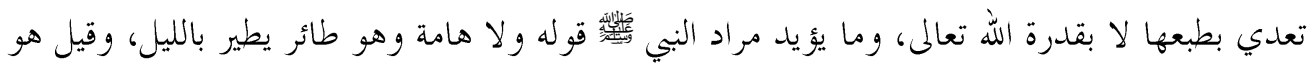

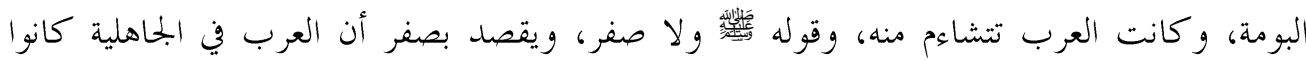
يزعمون بوجود حية في البطن يقال لها صفر تصيب الإنسان إذا جاع وتؤذيه وإذا تعدي فأبطل الإسلام

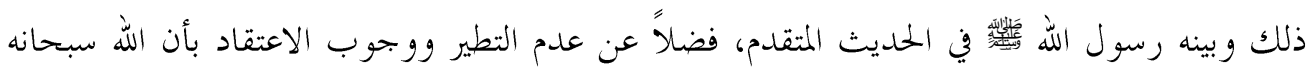

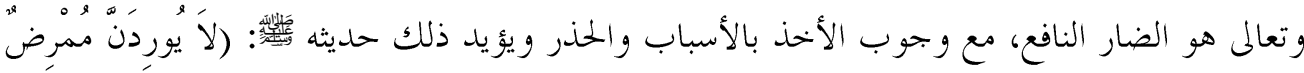

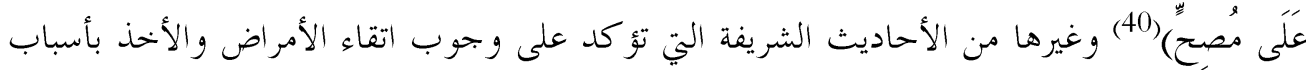
الوقاية والحندر (41). قال الإمام النووي: (أن حديث لا عدوى المراد به نفي ما كانت الجماهلية تزعمه وتعتقده أن المرض

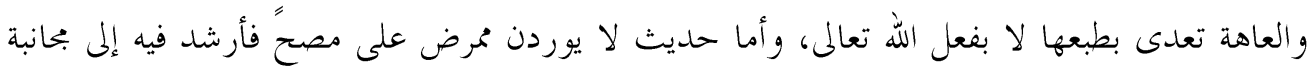

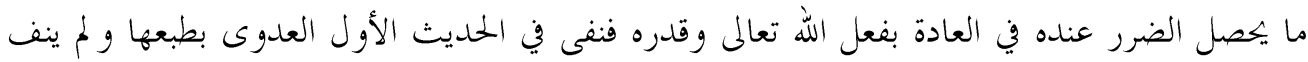


حصول الضرر عند ذلك بقدر الله تعالى وفعله وأرشد في الثاني إلى الاحتراز مما يكصل عنده الضرر بفعل الله وار ادته وقدرته)(42).

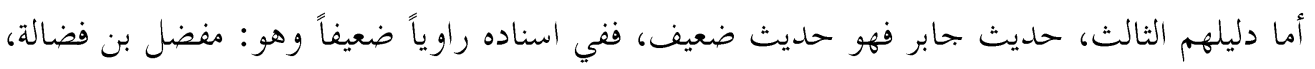

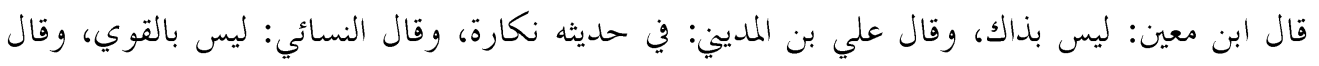

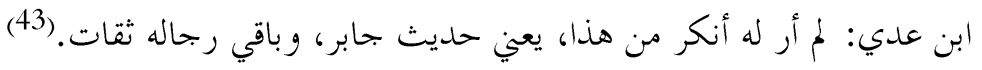

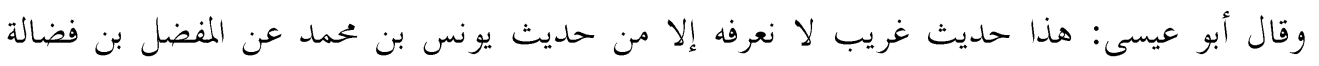
و المفضل بن فضالة هذا شيخ بصري، والمفضل بن فضالة شيخ آخر بصري أوثق من هذا وأشهر (44 هن

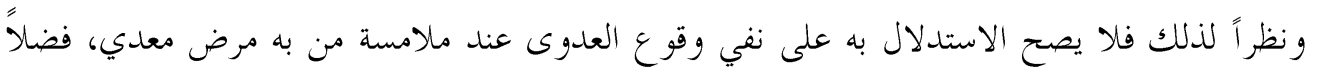

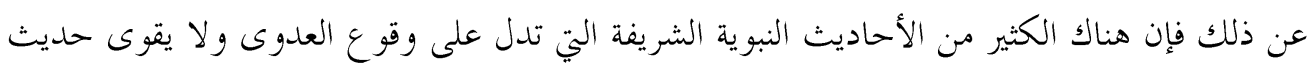

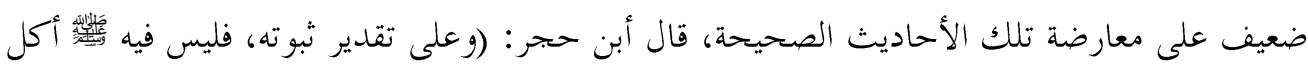

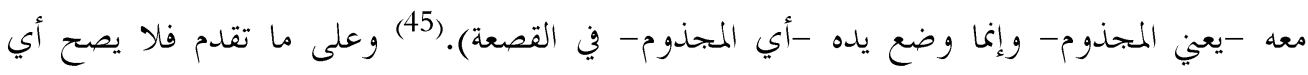

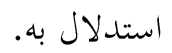

الرأي الراجح

بعد بيان أدلة المذهبين ومناقشتها والرد عليها يبدوا لنا أن الراجح ما ذهب إليه اصحاب القول الأول القائلين بثبوت العدوى، وهي واقعة في زمن الصحابة وتحديداً طاعون عمواس الذي حدث في في السنة

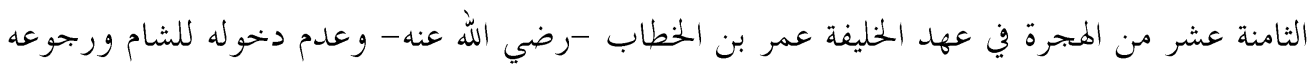

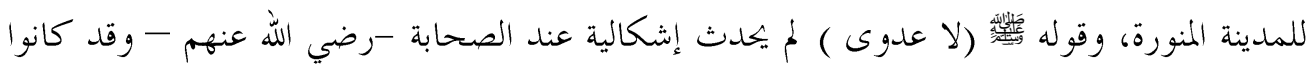

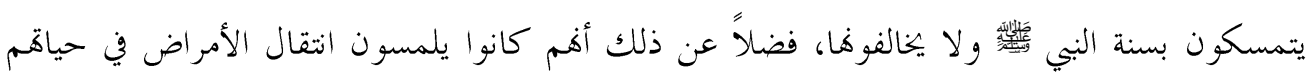
اليومية واصابة بعض الصحابة -رضي الله عنهم- بالطاعون وموقهم به في الشام، والطب قد أثبت انتقال

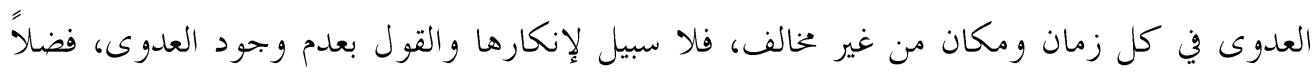

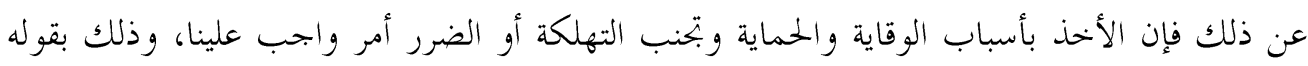

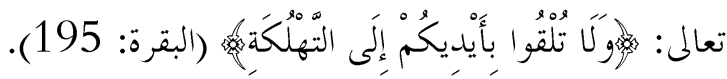

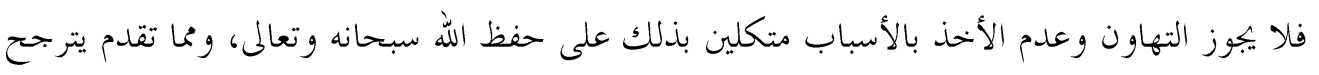
لدينا مذهب القائلين بثبوت العدوى ورع والله أعلم.

المطلب الثايي: حكم من تسبب بنقل العدوى.

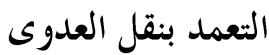


يتعمد بعض مرضى الأمراض المعدية، كمرض COVID 19 والإيدز بنقل المرض إلى غيرهم من الأصحاء،

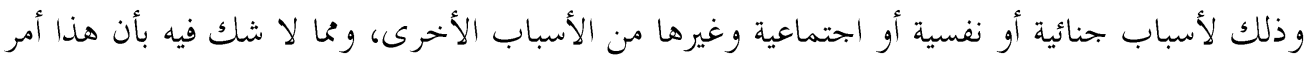

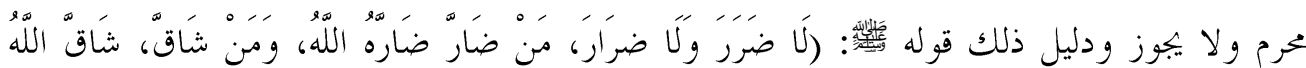

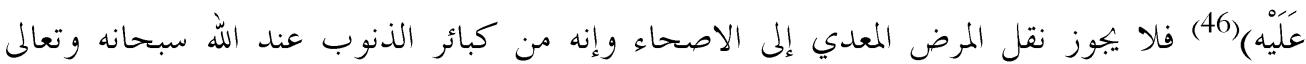
ويترتب عليه عذاب الله في الأخرة والقصاص في الدنيا، فكل من نقل العدوى إلى شخص أخر وأدى إلى إله لموته فهذا يطلق عليه الفقهاء مسمى القتل بالتسبب، فقد اتفق الفقهاء -رحمهم الله- على وجوب تهن القصاص في القتل العمد لكنهم اختلفو إي وجوب القصاص في القتل بالتسبب إلى قولين: القول الأول: القتل بالتسبب يوجب القصاص بشرط أن يتعمد المتسبب بالضرر وأن يفضي الضرر

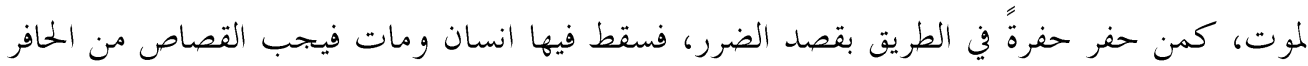

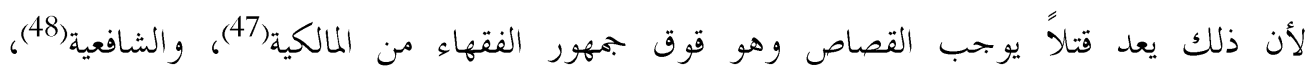
والحنابلة) القول الثالي: القتل بالتسبب لا يوجب القصاص كمن حفر حفرةً في الطريق فسقط فيها انسان ومات

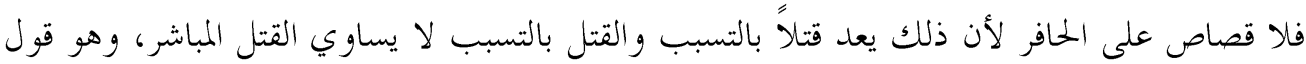

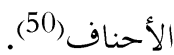
أدلة الفريقين: أدلة الفريق الأول:

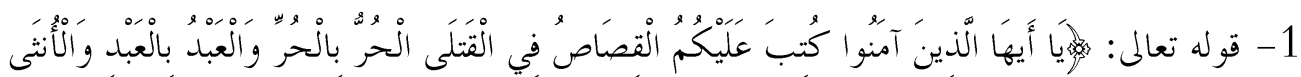

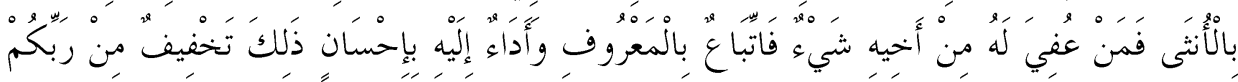

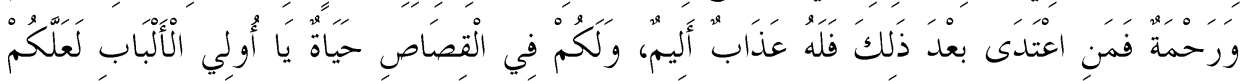

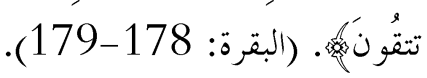

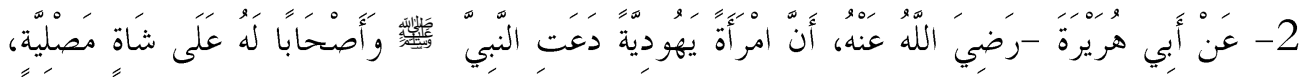

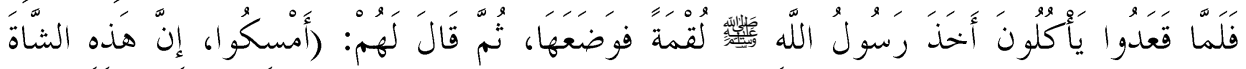

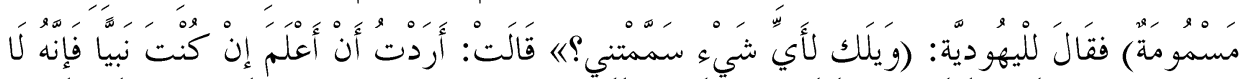

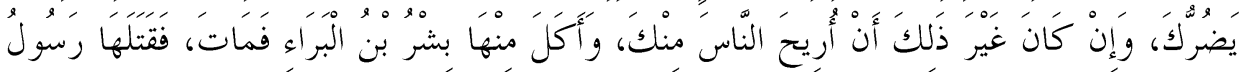
اللَّهم (51) 


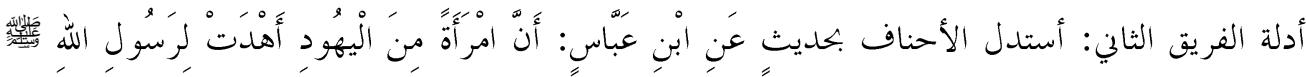

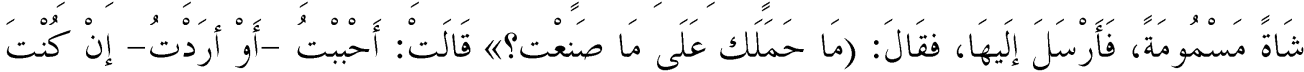

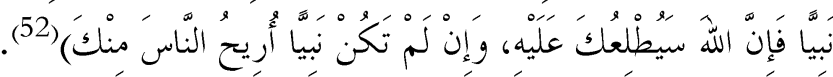

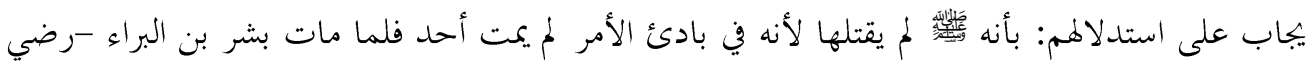

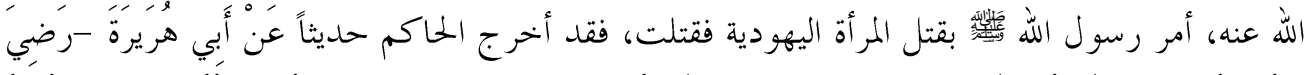

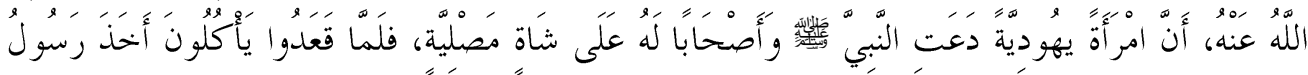

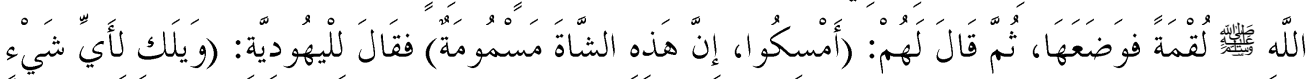

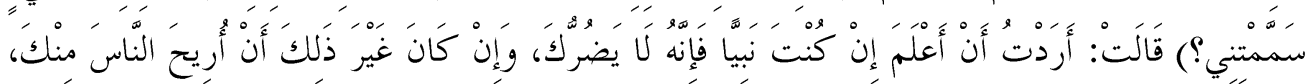

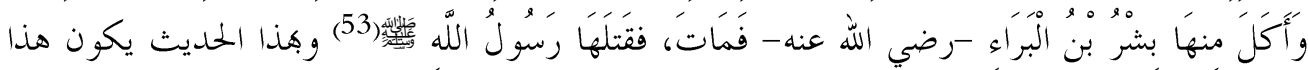
الاستدلال للجمهور لا عليهم كما بينا في أدلة الجمهور.

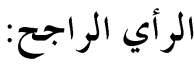
بعد بيان أدلة الفريقين ووجه الاستلال منها والرد عليها فالذي يتضح منها رجحان ما ذهب إليه الجمهور وذلك لقوة أدلتهم على من خالفهم، فضلاً عن ذلك أن بعض القتلة سيلجؤون إلى القتل بالأسباب الخفية التي تؤدي إلى القتل غالباً أو قطعاً كدس السم أو نقل العدوى ولأصبحت تلك طريقة للقتل بغية الإفلات من العقوبة فمن باب سد الذرائع يجب القول بعقوبة من تسبب بالقتل والله أعلم.

\section{الخطأ والجهل والإهمال والتقصير بنقل العدوى}

يقوم بعض مرضى الأمر اض المعدية كمرض COVID 19 والإيدز بنقل المرض إلى غيرهم من الأصحاء من غير تعمد كجهلهم بإصابتهم أو لاعتقادهم بأن مرضهم غير معدي أو لتقصيرهم في التحرز عن نقل المرض وغيرها من الأسباب الأخرى، ومما لا شك فيه بأن هذا أمر غير صحيح ويجب الانتباه له، فكل من نقل مرض معد إلى غيره بجهلٍ أو خطأ منه وتسبب بقتل نفس أو اتلاف عضواً وجبت عليه

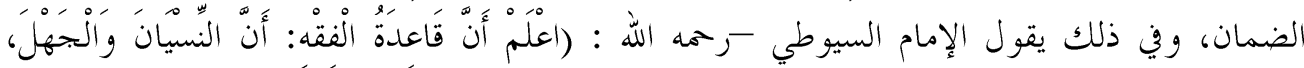

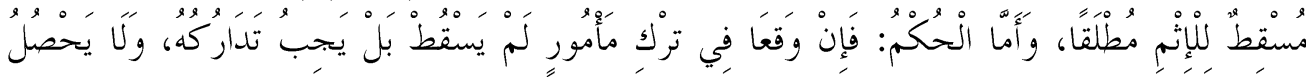

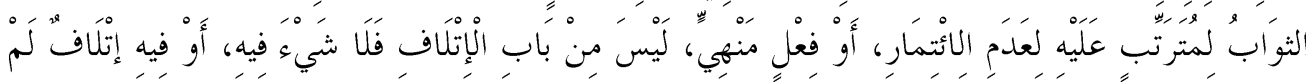

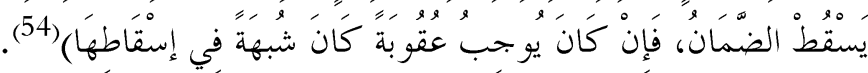
فكل خطأ يقع من قبل الأطباء ويؤدي إلى ضرر بالأخرين يعاقب عليه الطبيب لأنه يعد بمثابة استخفاف واستهانة بأرواح الخلق ويجب عليه الضمان شرعاً لأن خطأه أدى إلى إتلاف عضو أو ر.ما موت نفس، 
قال أبن القاسم: (لا ضمان على طبيب وحجام وخاتن وبيطار إن مات حيوان بما صنعوا به إن لم

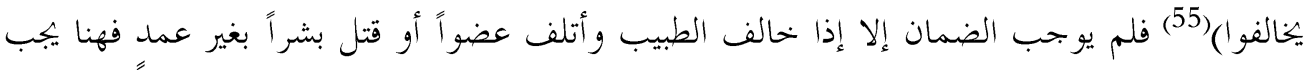
عليه الضمان.

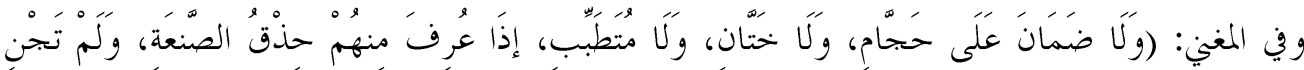

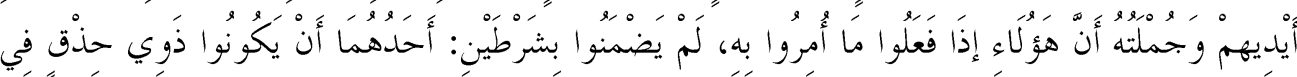

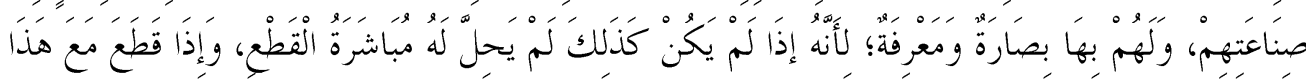

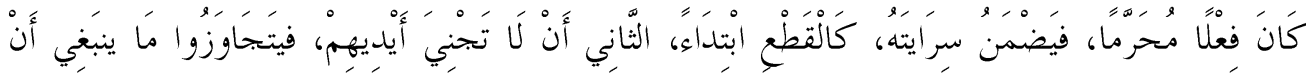

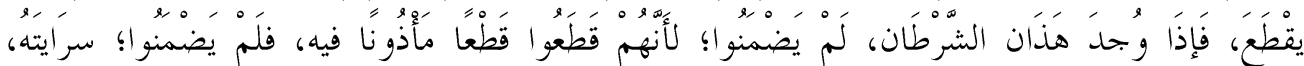

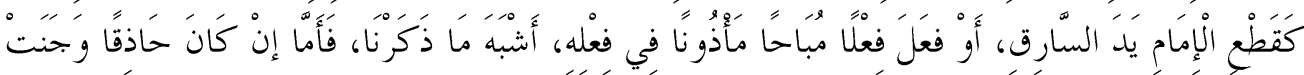

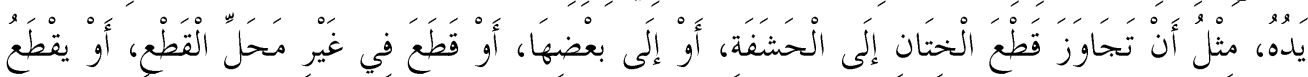

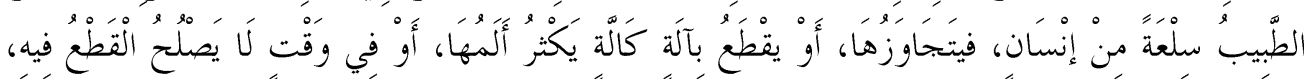

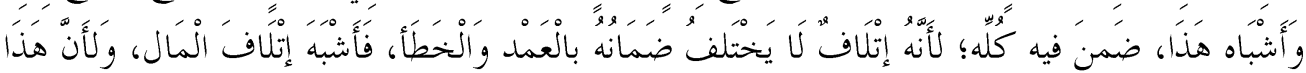

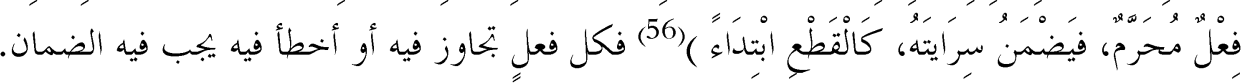

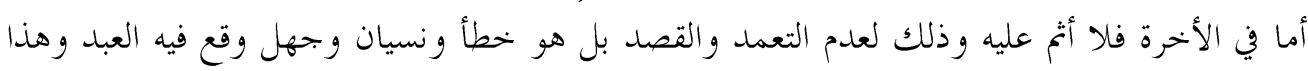

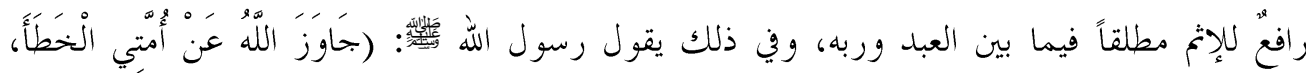

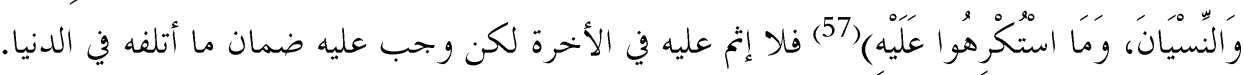

\section{المبحث الثالث: صور تطبيقية للتدابير الوقائية لمكافحة العدوى في الشريعة الإسلامية.} ين الشريعة الإسلامية الكثير من التدابير الوقائية التي تحد من العدوى وتمنع انتشارها وتوقف انتقاها، ومن تلك التدابير: كراهة النفخ في الإناء لغرض تبريده، وتغطية أواني الشراب والطعام، ووجوب تلغئ تغسيل

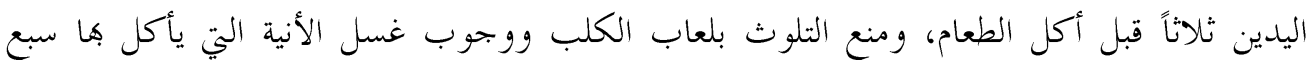
مرات، وكراهة البصاق على الأرض، والنهي عن التبول و التبرز في المياه، وغيرها كثير من التعليمات النبوية التي تحث على الحفاظ على النظافة، فكل ذلك من شأنه أن يهد من انتقال العدوى ويمنع انتشارها ومن تلك التدابير:

أولاً: كر اهة النفخ في الإناء أو التنفس فيه أو تبريد الطعام اختلف الفقهاء حكم تبريد الطعام في الإناء والنفخ فيه، إلى قولين: 
القول الأول: كراهة التنفس في الإناء والنفخ فيه وإليه ذهب الحنفية(58)، والمالكية(59)، والشافعية(60)،

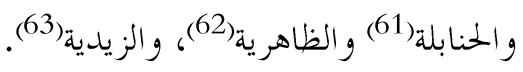

القول الثالي: عدم كراهة النفخ في الإناء، وبه قال أبو يوسف -رحمه الله : من الحنفية إلا أنه استثنى ما

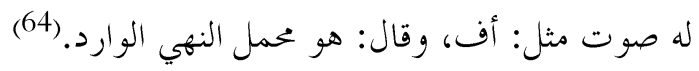

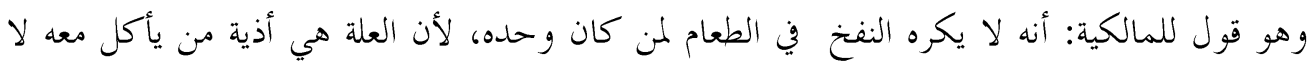

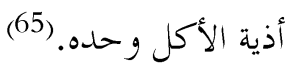

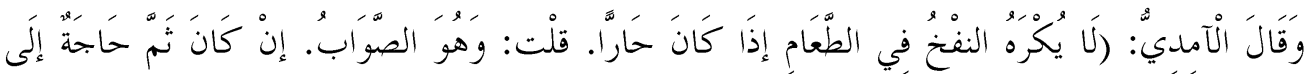

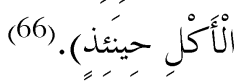

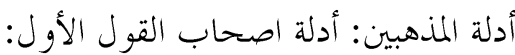

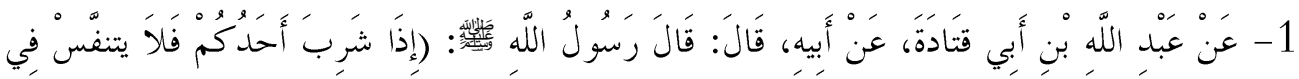

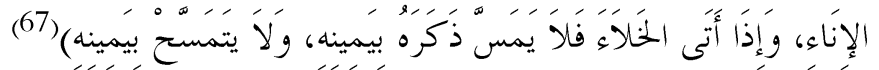

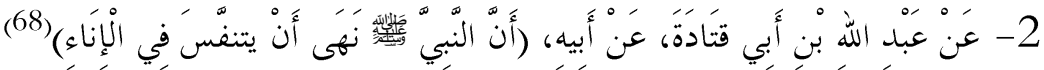

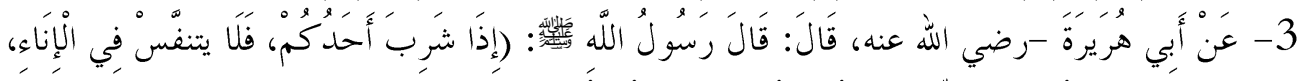

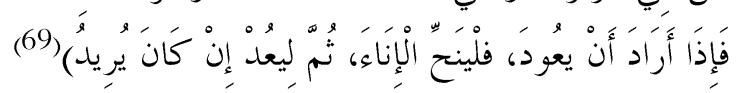

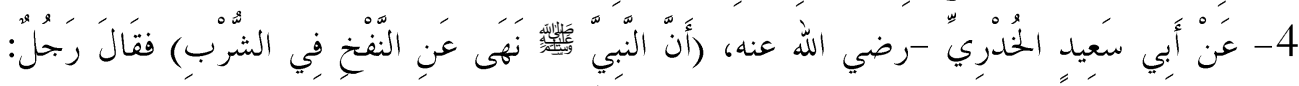

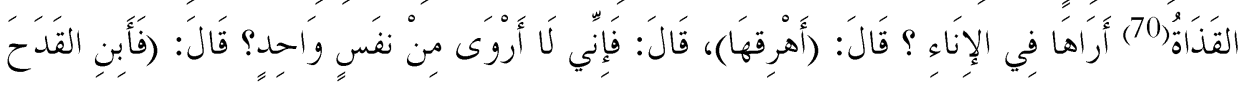

$$
\begin{aligned}
& \text { إذََنْ عَنْ فِيكَ)(71) } \\
& \text { أدلة اصحاب القول الثاني: }
\end{aligned}
$$

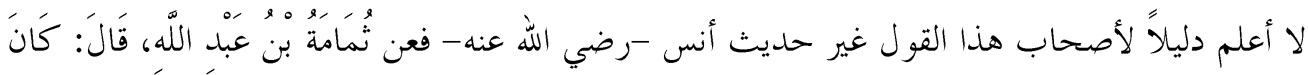

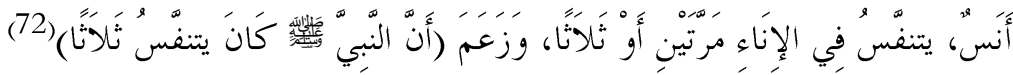
القول الراجح بعد عرض أدلة المذهبين يبدوا لي الراجح ما ذهب إليه أصحاب القول الأول القائلين بكراهة النفخ في الطعام، وقد ثبت علمياً ومن خلال التجربة أن النفخ في الطعام يتسبب في تلويثه وبالتالي انتقال الجر اثيم

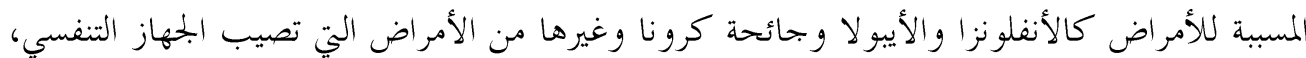

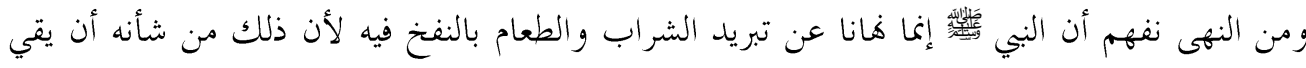
الإنسان من انتقال العدوى إليه وتقليل مخاطر اصابته بالأمراض المعدية. 


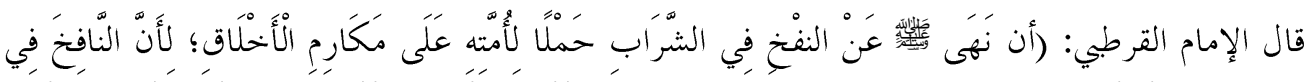

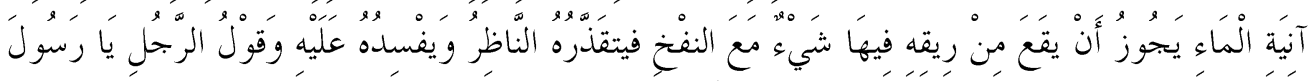

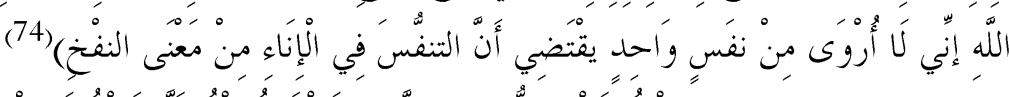

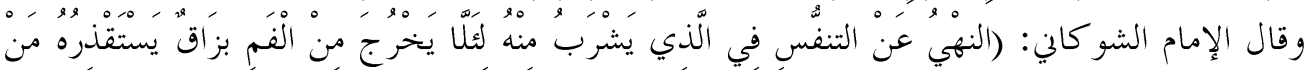

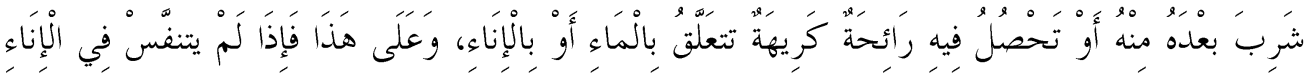

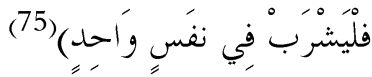
أما حديث أنس -رضي الله عنه- فلا يقوى على معارضة ما تقدم من أحاديث صحاح ويمكن حمله

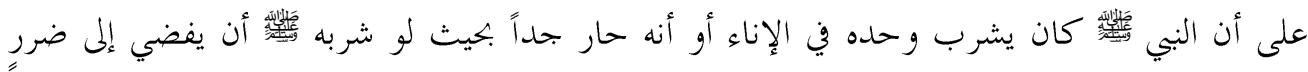
أكبر وأعظم، و كذلك مخالفة أبا يوسف -رحمه الله- والآمدي وقول المالكية، فهم لم يقولوا بعدم الكراهة بالمطلق، ولكن قيدها أبو يوسف بصدور الصوت والعلة فيه هو أن يتأذى أو يتقزز أو يستقذر السامع صدور الصوت، وقيد الآمدي بحرارة الطعام والشرب لمخافة أن يفضي الطعام الحار والشراب إلى مفسدة أكبر وأعظم من تبريده، والمالكية بعدم الكراهة لمن يأكل و حده وذلك بعدم انتشار العدوى لغيره لأنه وحلده يأكل ويشرب في الإناء، فالراجح و اللّ أعلم ما ذهب إليه أصحاب القول الأول.(76)

\section{ثانياً: منع البصاق والنخامة على الأرض}

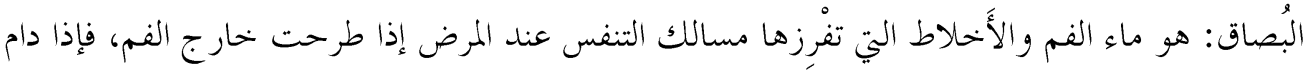
فيه فهو ريق، وقل تقلب الصاد زاياً أو سيناً فيقال: بزاق وبساق الريّ. (77) النخامة: بضم النون، ما يدفعه الانسان من صدره أو أنفه من بلغم أو نهوه.(78) أختلف الفقهاء في حكم البصاق والنخامة على الأرض في الأماكن العامة كالمساجد إلى قولين: القول الأول: حرمة البصاق على الأرض في الأماكن العامة كالمسجد، وبه قال الأحناف(79)، و الشافعية)(80)

القول الثائ: كراهة البصاق على الأرض في الأماكن العامة كالمسجد، وبه قال الحنابلة(81)، والمالكية إذا كان المسجد مفروش بالخصير أو مبلط أو لا يتمكن الباصق من دفنها ويجيوز عندهم إذا كان المسجد

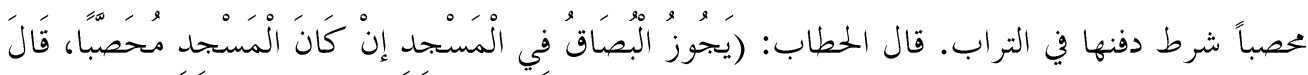

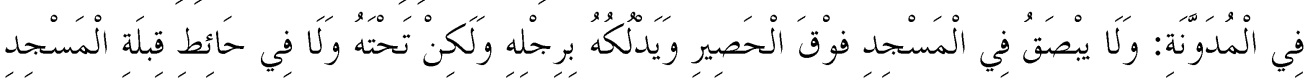

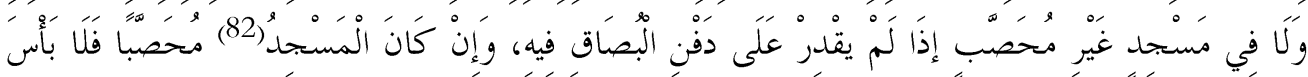

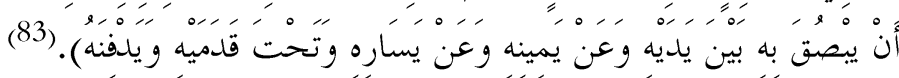


أدلة الفريقين: أدلة اصحاب القول الأول

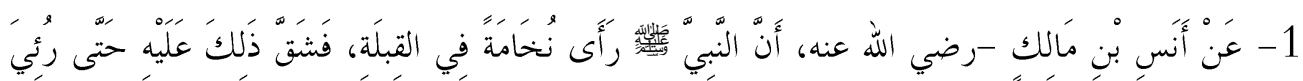

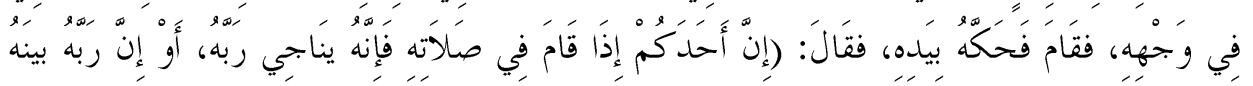

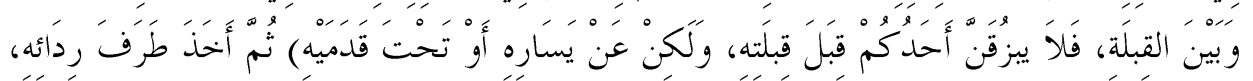

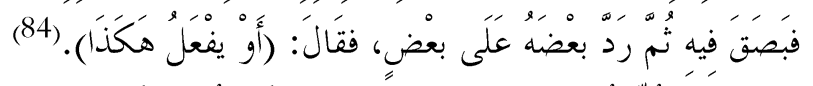

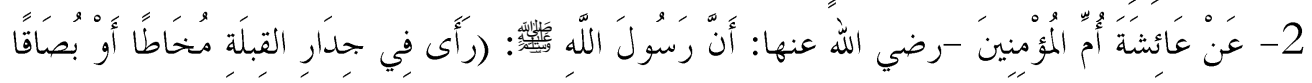

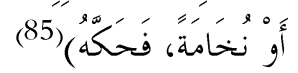

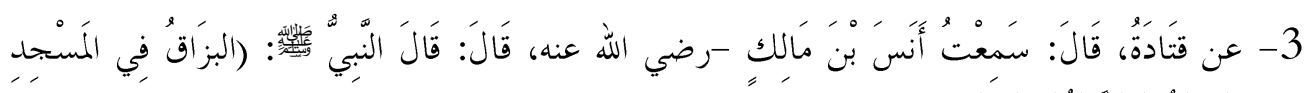

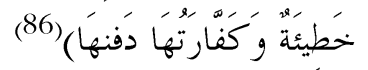

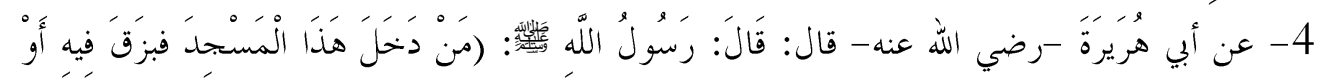

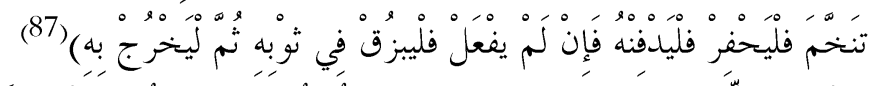

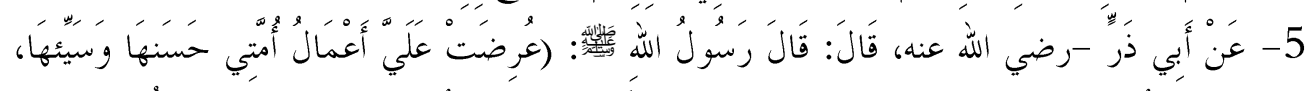

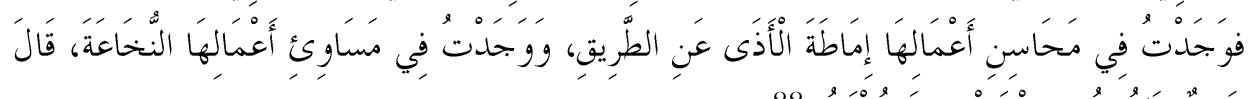

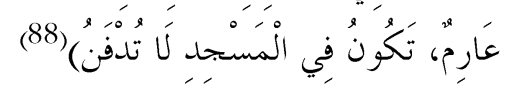
أدلة اصحاب القول الثاني

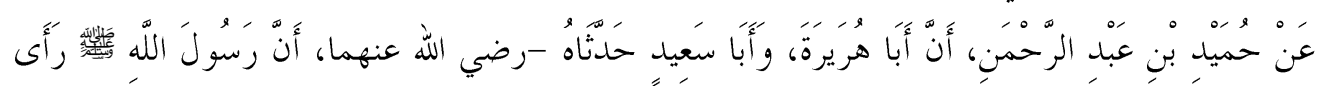

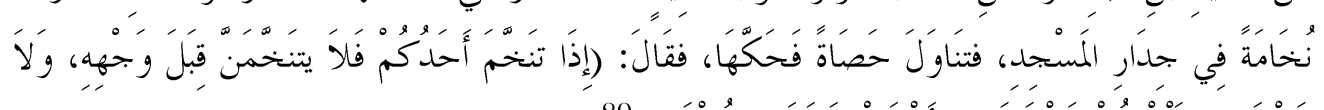

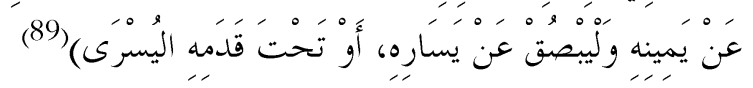
الرأي الراجح بعد عرض أدلة الفريقين يبدوا لي الراجح ما ذهب إليه أصحاب القول الأول وذلك لقوة أدلتهم، فضلاً

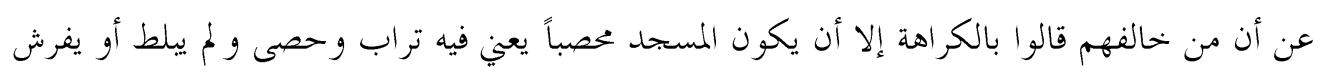

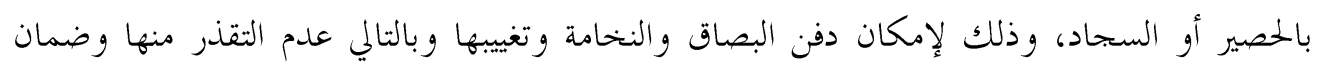

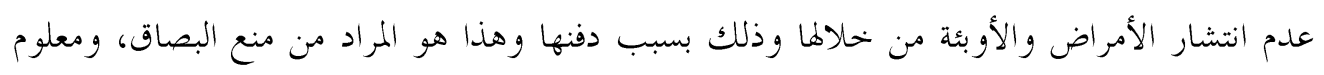

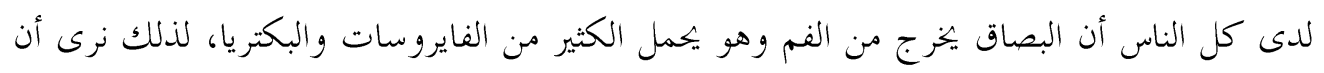

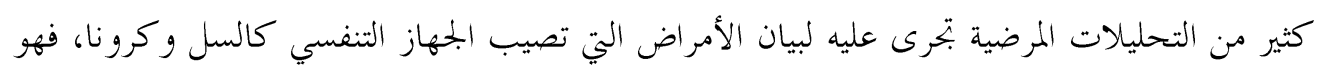

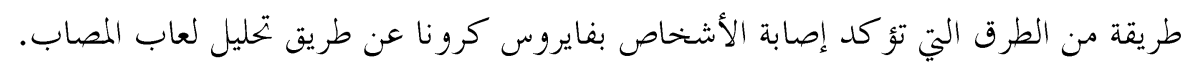


وكذلك يحلق بحرمة البصاق والنخامة في الأماكن العامة كل شيء مستقذر أو من شأنه أن ينشر

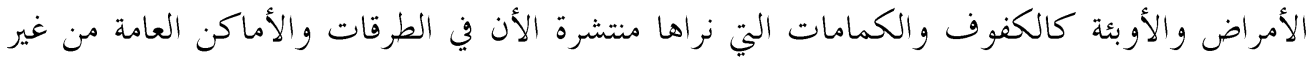
مراعاة للذوق العام أو لانتشار الأوبئة والأمراض في ظل وله جائحة كرونا.

\section{ثالثاً: التطهر من نجاسة الحيوانات كالكلب}

بعض الحيوانات تتغذى على النجاسات والقذارات والميتة، لذلك يكون لعاها بجساً ويحمل البكتريا

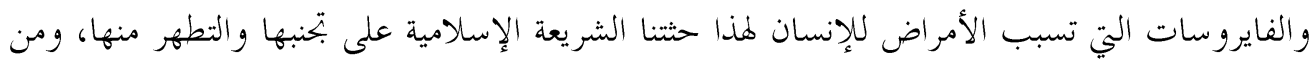
ذلك غسل الإناء الذي يلغ فيه الكلب سبع مرات. ولكنهم اختلفوا في وجوب استعمال التراب مع الماء في التطهير إلى قولين: القول الأول: يجب أن يكون التراب مع الماء في التطهير من بنحاسة الكلب والخنزير وما تولد منهما وبه قال الشافعية(90)، و الحنابلة(91). القول الثالي: لا يجب أن يكون التراب مع الماء في التطهير من بنحاسة الكلب والختزير وما تولد منهما وبه قال الأحناف (92)، والمالكية(93). أدلة الفريقين: أدلة الفريق الأول:

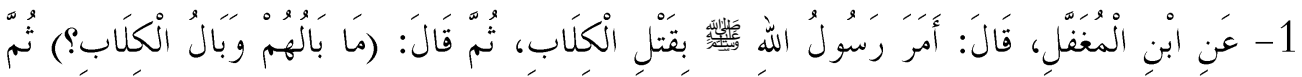

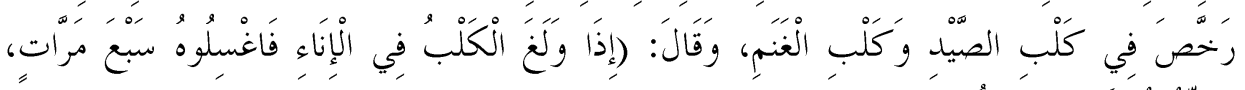

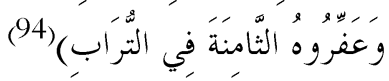

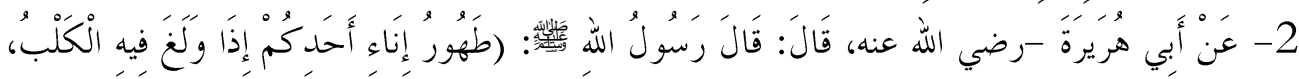

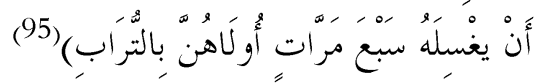

$$
\begin{aligned}
& \text { أدلة الفريق الثاني: }
\end{aligned}
$$

استدل أصحاب القول الثاني .ما استدل منه اصحاب القول الأول من غير ذكر للتراب، فقد جاء في سنن

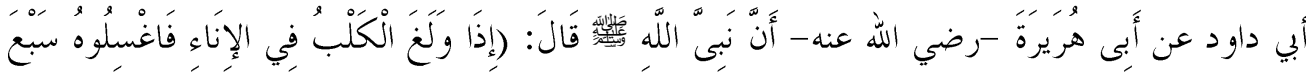

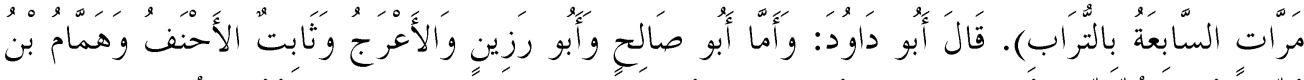

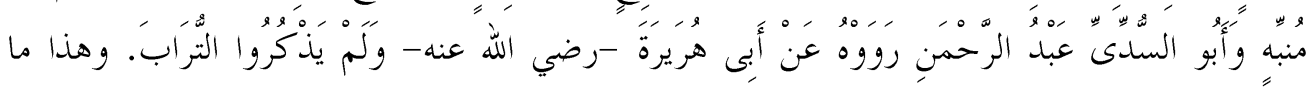

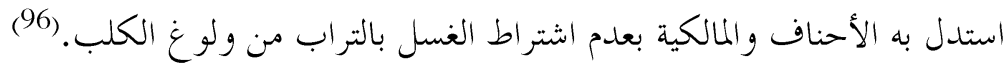
الرأي الراجح 
بعد بيان أدلة الفريق فالراجح والله أعلم من قال: بوجوب الغسل بالتراب وذلك لقوة أدلتهم على من

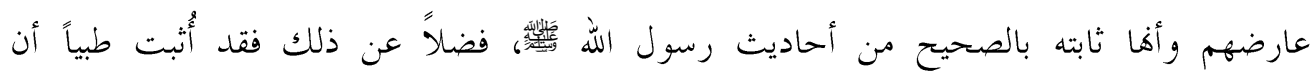

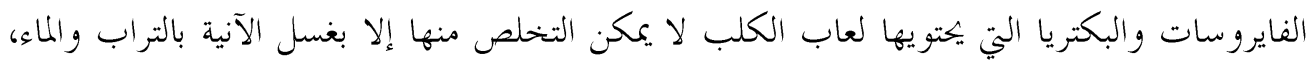

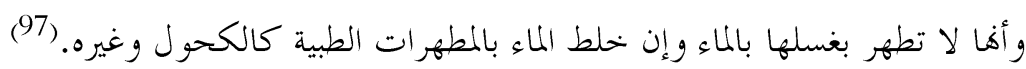

\section{رابعاً: منع التبرز والتبول في الموارد العامة}

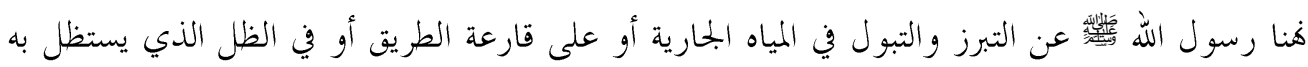

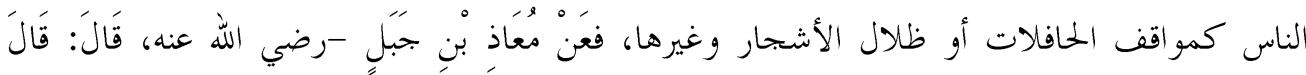

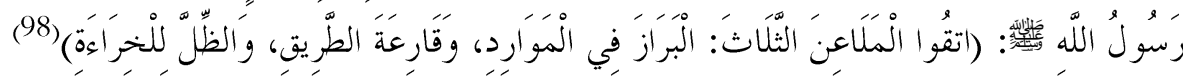

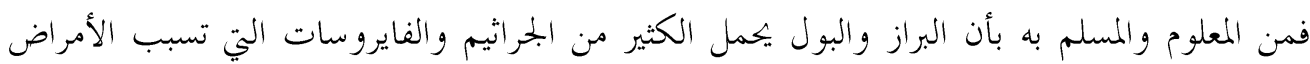
للإنسان كالكوليرا والتيفوئيد والبلهارسيا وديدان الجهاز الهضمي كدودة البقرة الشريطية وغيرها الكثير

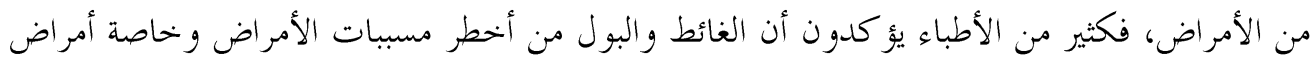

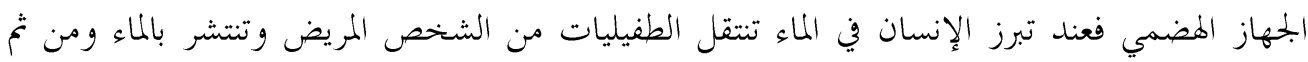

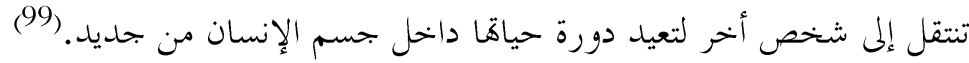

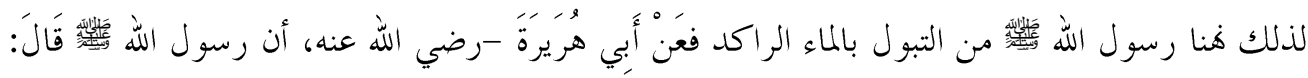

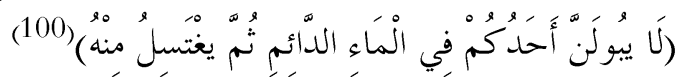

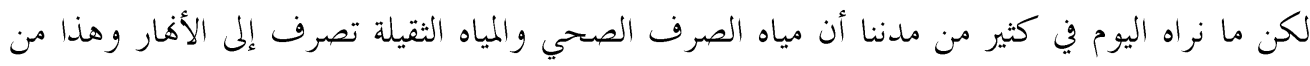
شأنه أن يسبب الكثير من الأمراض والمشاكل الصحية وهو أمر محرم ومنهي عنه شرعاً بدليل الأحاديث

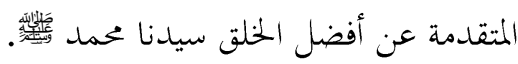

\section{خامساً: في المستيقظ أن يضع يده في إناء حتى يغسلها ثلاثاً}

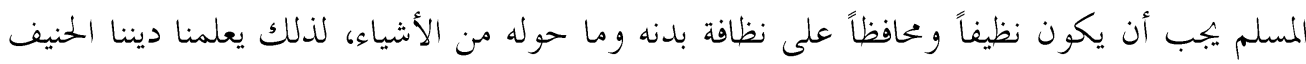

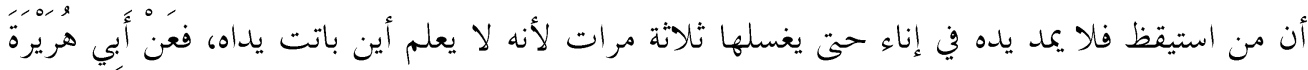

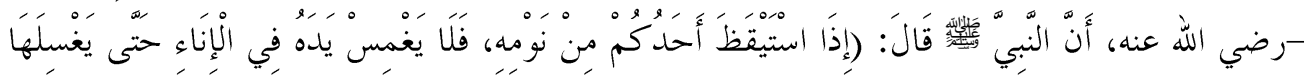

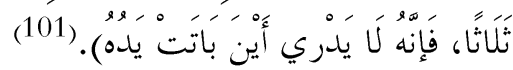
فمن الممكن أن يده مست فرجه وهو مصاب بأمراض اضن الجهاز الهضمي كالديدان، فتتنقل تلك الديدان

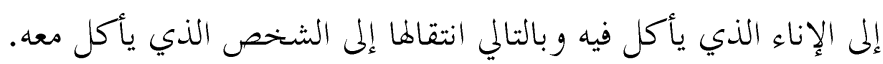




\section{سادساً: يجب تغطية آنية الطعام والشراب}

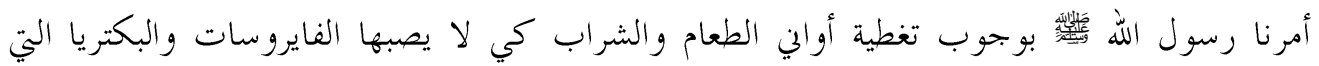

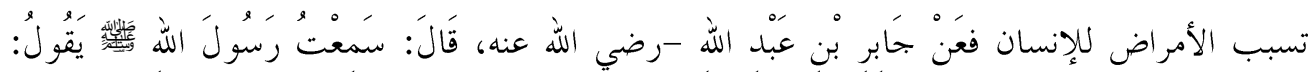

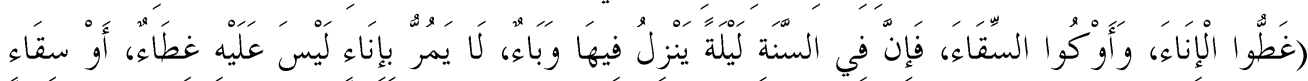

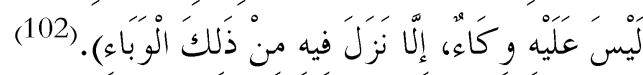

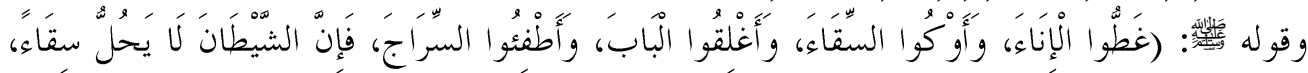

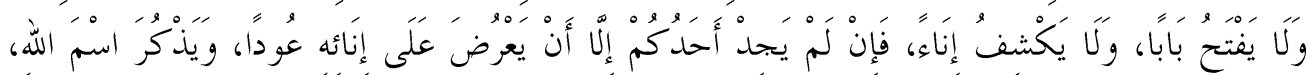

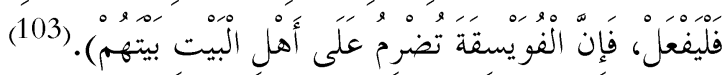

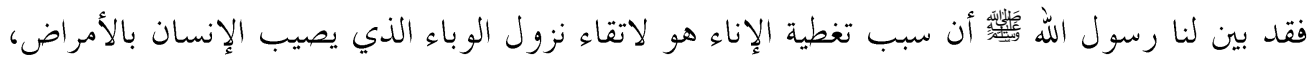

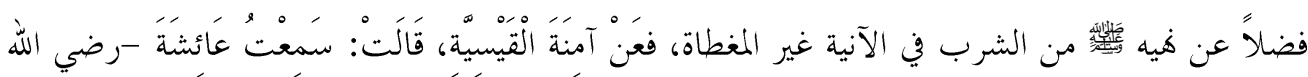

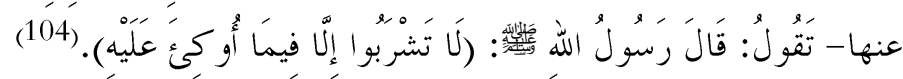

\section{سابعاً: تحريم أكل الميتة والدم ورلحم الحختير}

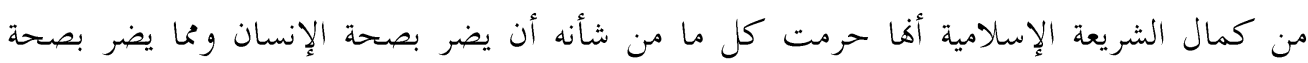

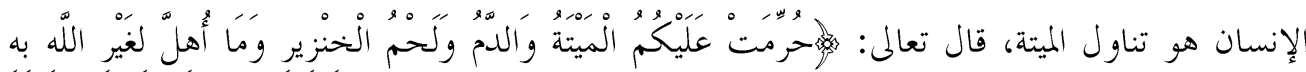

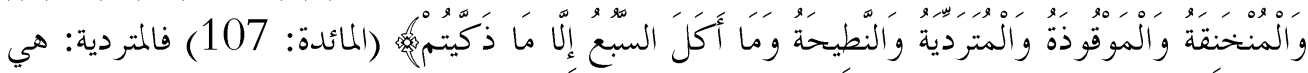
الحيو ان الذي مات بسبب سقوطه. والموقوذة: هي المقتولة بضربة عصا أو حجر أو نحو ذلك. و النطيحة:

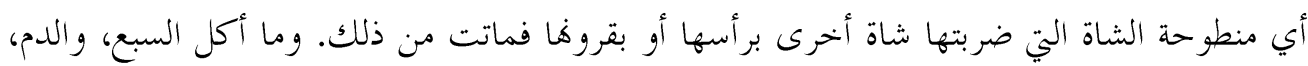

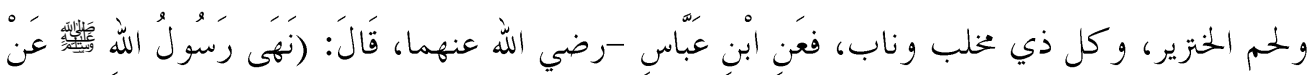

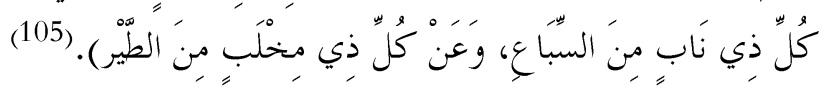
وقد أثبت طبياً أن الجراثيم تتكاثر في جسم الميتة وتبدأ عمليات التعفن والتحلل فور الموت، ويساعد في دئ

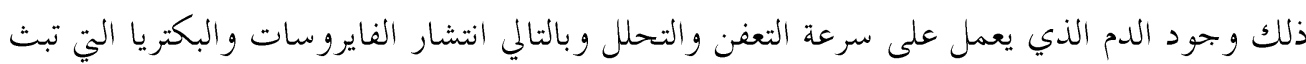

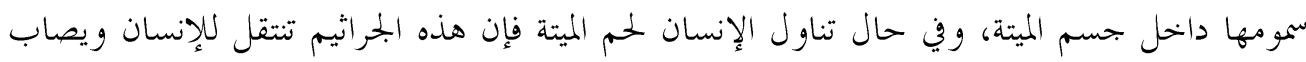

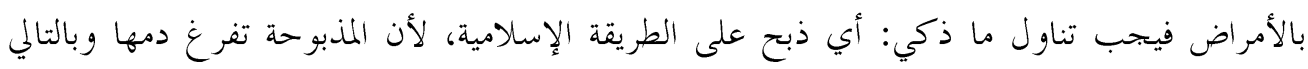

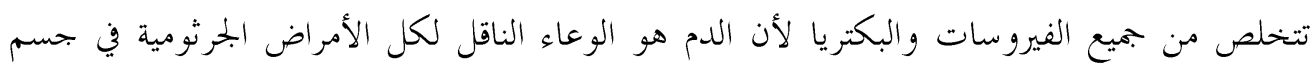
الكائن الحي. (106) 


\section{ثامناً: تحريم الزنا}

من التدابير الوقائية التي جاءت ها الشريعة الإسلامية هي تحريم الزنا وذلك صيانة للأنساب وحفظاً للجهاز التناسلي من انتقال العلدوى الأمراض كالإيدز وغيره، قال تعالى:

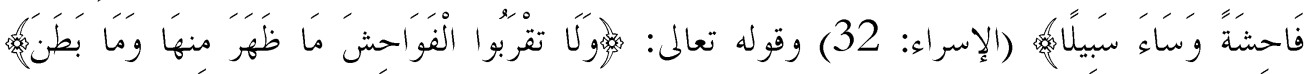
(الأنعام: 151) و الزنا من أعظم الفواحش وأكثرها ذنباً فهو من الكبائر اليت هانا الله سبحانه وتعالى

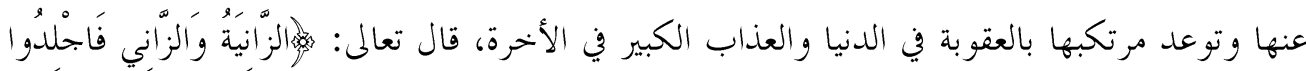

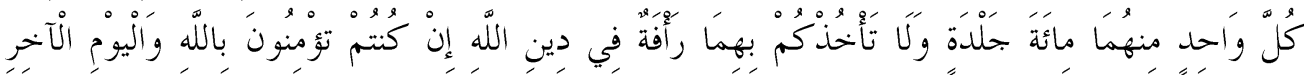

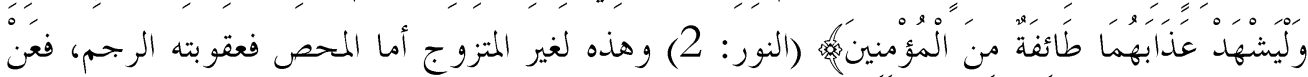

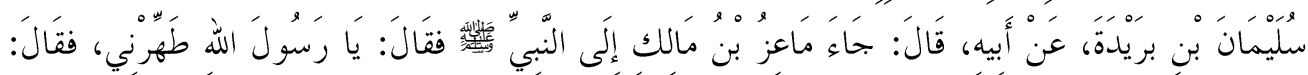

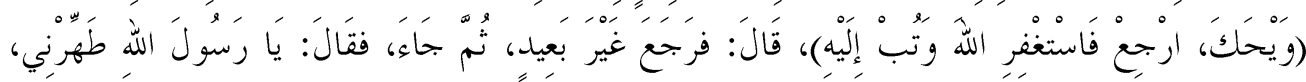

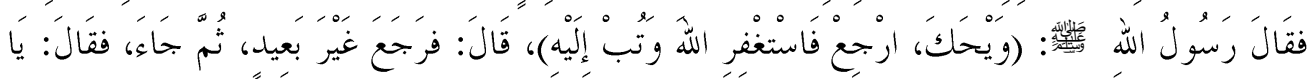

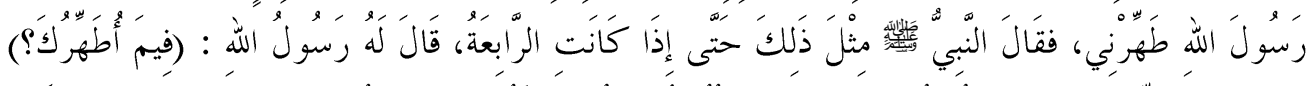

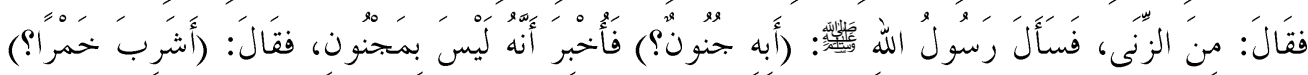

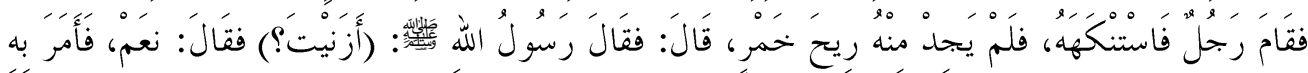

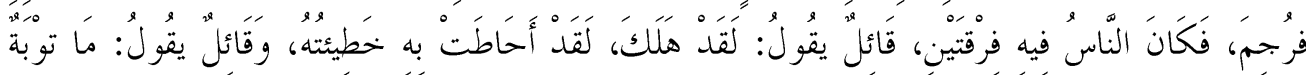

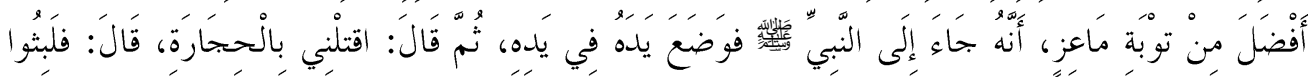

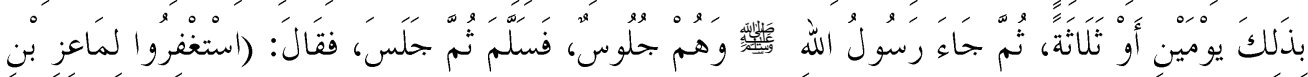

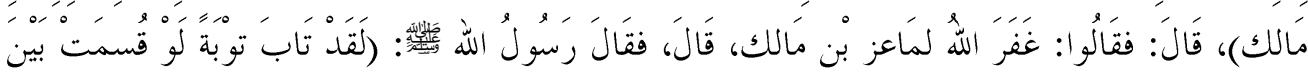

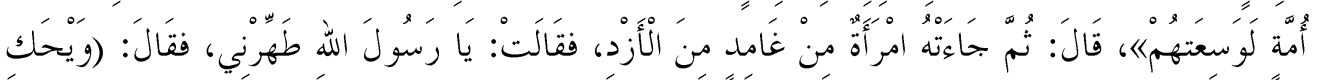

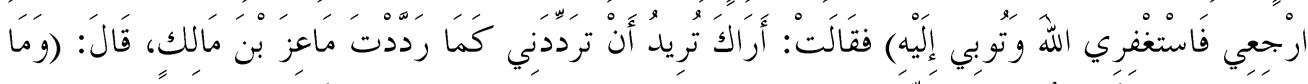

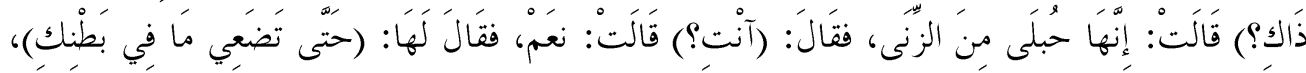

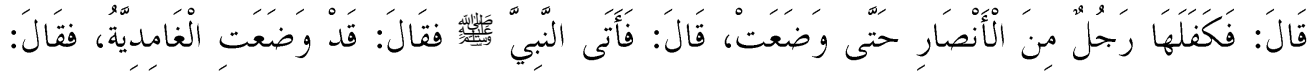

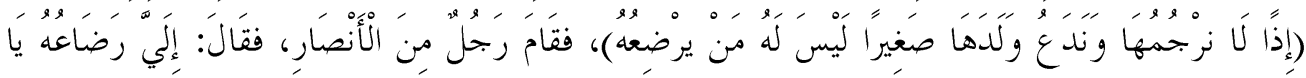

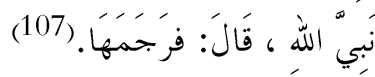

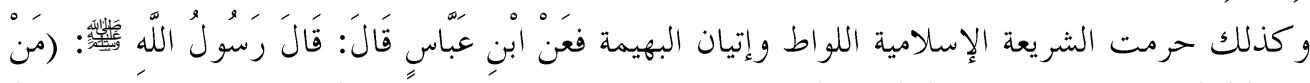

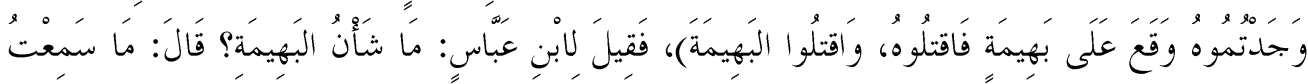




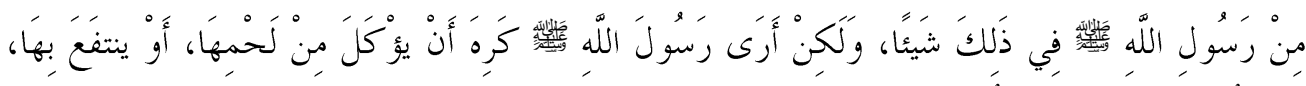

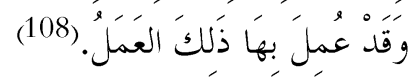

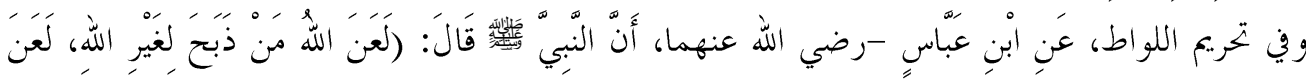

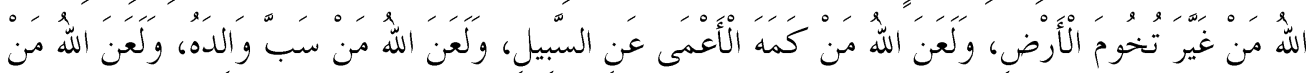

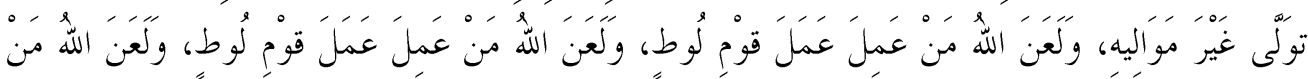

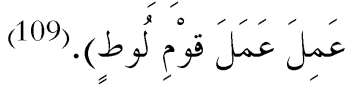
فهذه الآيات الكريمة والأحاديث الشريفة تبين لنا عظمة الشريعة الإسلامية في المحافظة على سلامة

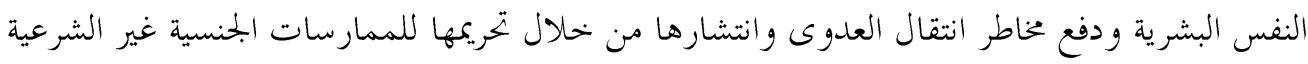

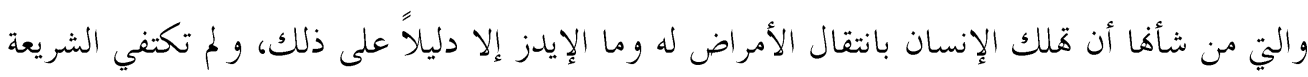

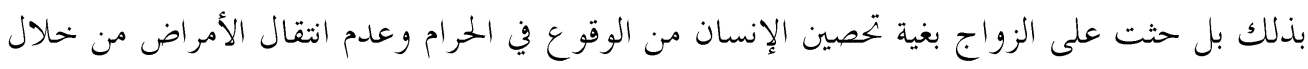

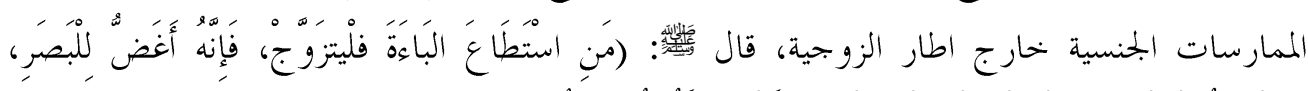

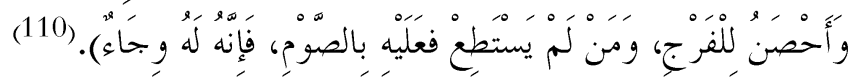

\section{تاسعاً: منع الخُورج والدخول من الأرض الموبوءة}

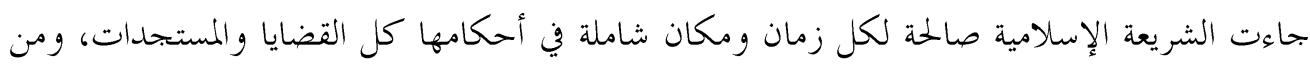

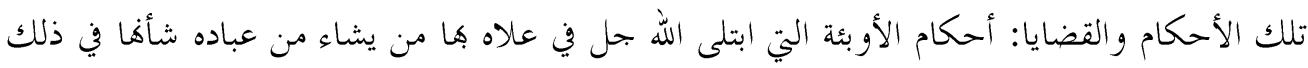

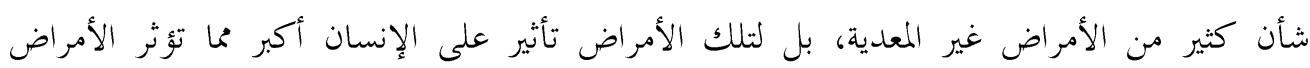

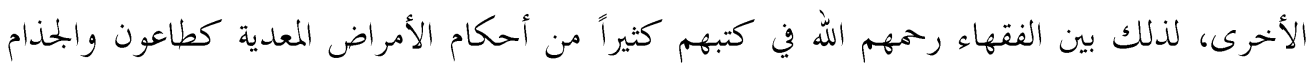
وغيرها من الأمراض المعدية الأخرى، وما جائحة كرونا إلا مرض من تلك الأمراض التي تناولها فقهاؤنا

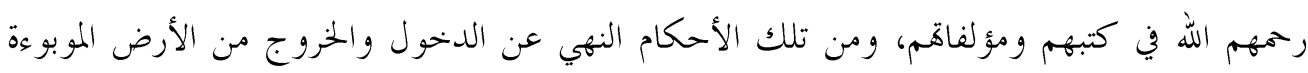

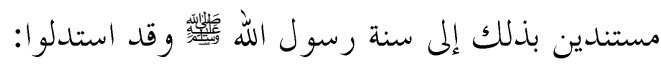

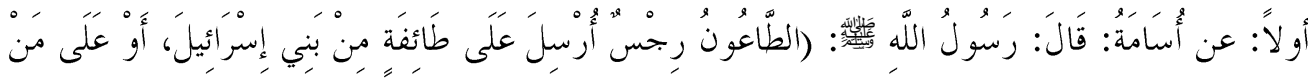

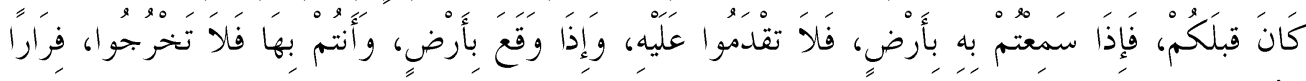
من (111)

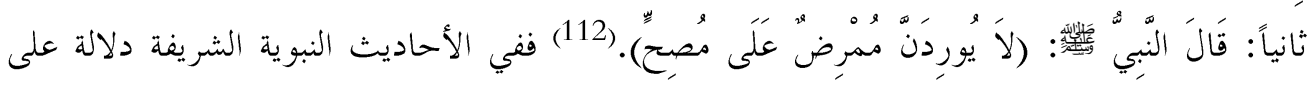

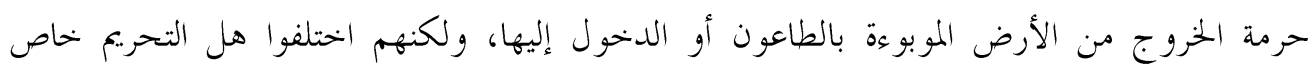

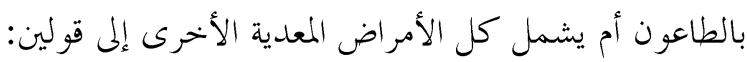


القول الأول: حرمة الخروج من الأرض الموبوءة بالطاعون أو الدخول إليها ولا فرق بين مرض معد وأخر، وهو قول جمهور أهل العلم و لم أعرف لهم مخالف غير السيوطي والهيتمي. (113)

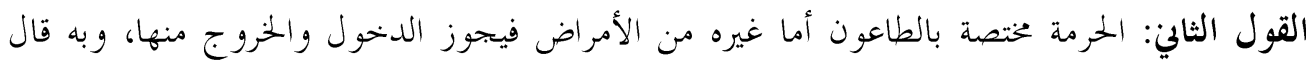

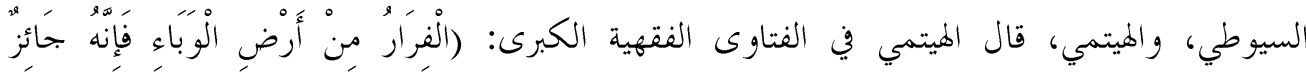

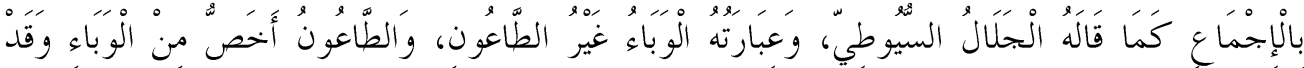

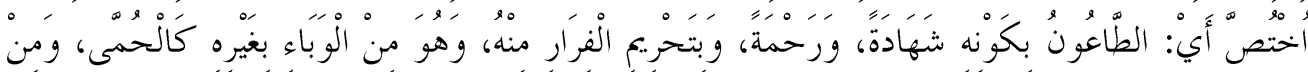

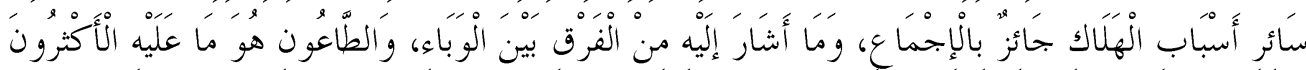

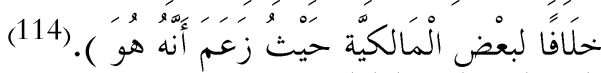
أدلة أصحاب القول الأول: استدل أصحاب القول الأول بعموم الأدلة السابقة على حرمة الخروج والدخول من الأرض الموبوءة بالطاعون أو بغيره من الأمراض الو بائية الأخرى.

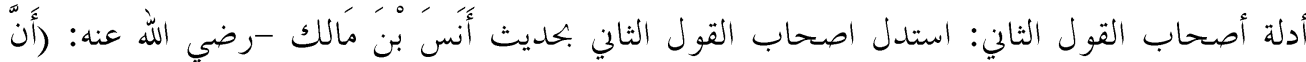

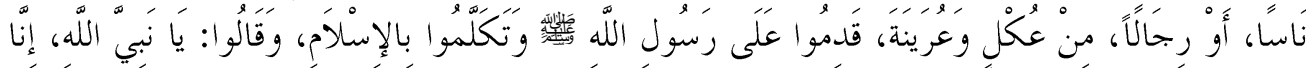

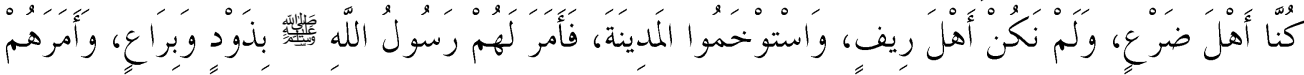

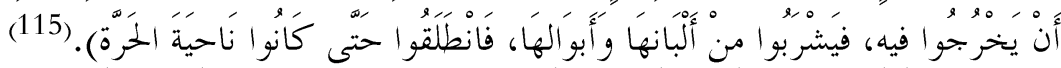

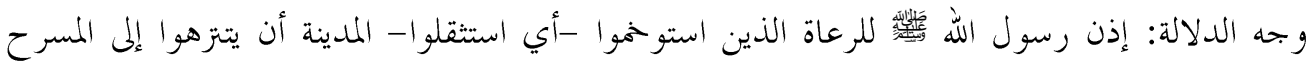
فيكونو ا فيه حتى يصبحوا.(116) يباب على ذلك: أن المدينة المنورة لم يكن فها وباءُ أو مرض، واستوخامهم العيش في المدينة بسبب طبعهم وطريقتهم في العيش فهم سكن البو ادي و لم يألفو المياة المدينة. (117)

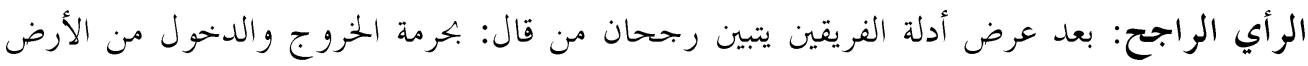

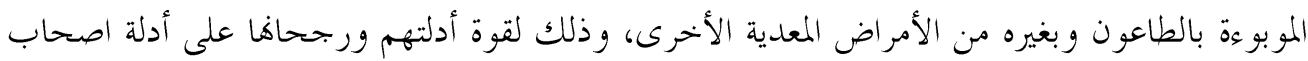

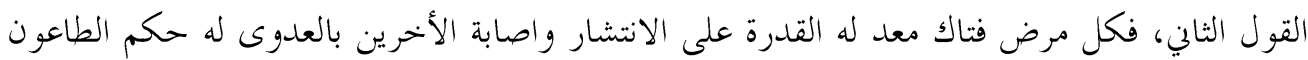
ولا فرق بينهما لأن الشريعة الإسلامية لا تفرق بين متشاهين، والوقاية من الأمراض فيه مصلحة حفظ النفس البشرية وهذا مقصد الشريعة الإسلامية.

\section{عاشر اً: منع زيارة المريض للسليم والعكس}

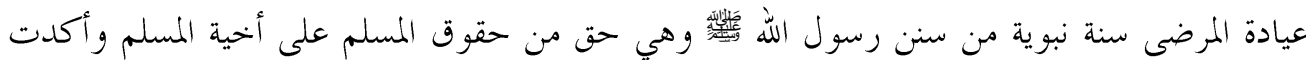

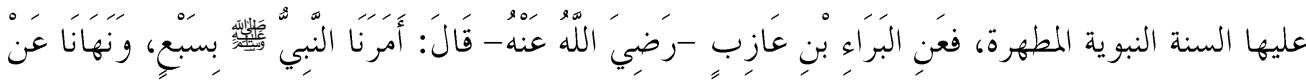




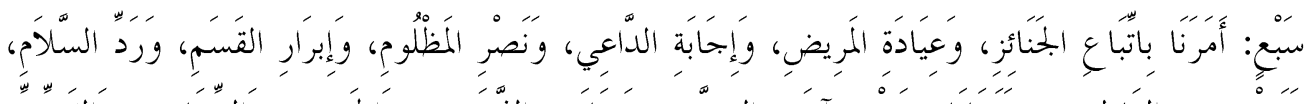

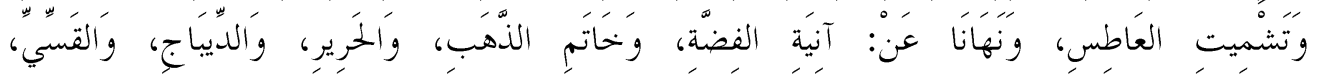

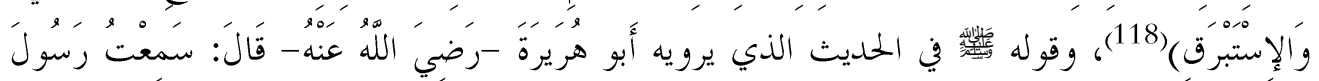

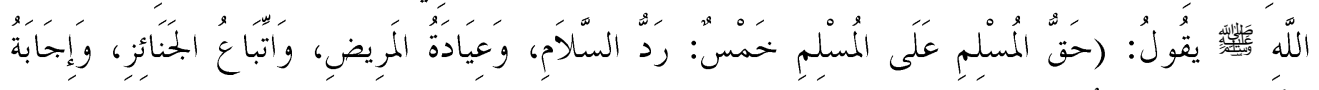

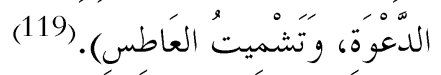
فهذه العيادة لمن كان مريض .كرض غير معدي، أما من كان مريض .كرض معدي فالقول الفصل فيه للأطباء فإذا أوصى الأطباء بعد الزيارة فأنه يجبب الالتزام بتعليماهم وعدم زيارة المريض حفظاً للنفس البشرية وصيانة" لها من الأذى، ويكتفى بالسؤال والاطمئنان على المريض من خلال برامج التواصل

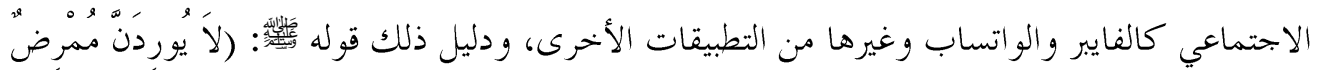

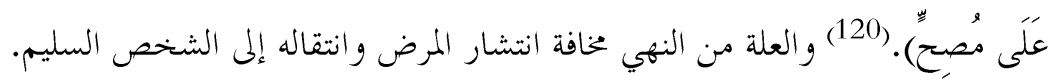

الخاتمة:

وفيها أهم النتائج و التوصيات

\section{النتائج}

1- من عظمة الشريعة الإسلامية و كمالها وصلاحها لكل زمان ومكان أها بينت الكنير من التدابير الوقائية للحد من انتشار الأمراض المعدية قبل الطب بعشرات بل مئات السنين. 2- التدابير الوقائية: وهي الإجراء التي يهكم هـا على الجاني وفقاً للقانون، وهي الإجراءات الوقائية التي يقوم بها ذوي المهن الصحية للحد من الأمراض ومنع انتشارها.

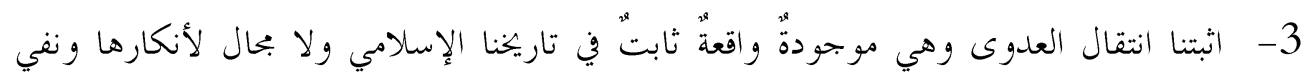
وقوعها. 4- لا يجوز التعمد بنقل العدوى ومن تعمد بنقلها فهو أتم وبتجب علية العقوبة، فلا يجوز نقل المرض المعدي إلى الاصحاء وهو من كبائر الذنوب ويترتب عليه عذاب الله في الأخرة والقصاص في الدنيا، فكل من نقل العدوى إلى شخص أخر وأدى لموته فهذا القتل بالتسبب، و اتفق فيه الفقهاء

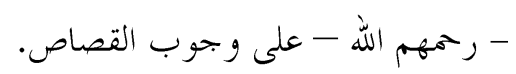

5- من تسبب بنقل العدوى تقصيرًا و جهالاً و اهمالاً بالخطأ من غير تعمد فلا إثم عليه في الأخرة لكن

وجب عليه ضمان ما أتلفه في الدنيا. 
6- من التدابير الشريعة التي اتخذها الشريعة الإسلامية كراهة النفخ في الإناء أو التنفس فيه أو تبريد

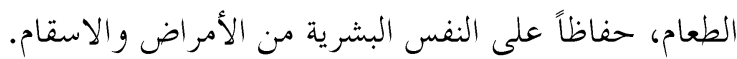

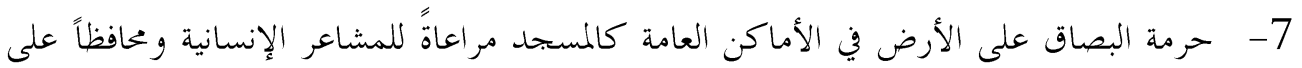

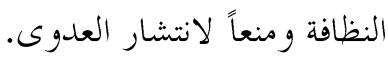

8- وجوب التطهر من بناسة بعض الحيوانات كالكلاب والحنازير التي تنقل الأمر اض لإنسان.

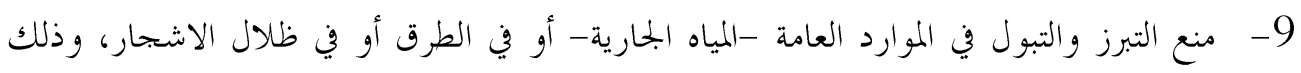
لأن البراز والبول يحمل الكثير من الجراثيم والفايروسات التي تسبب الأمراض لإِنسان كالكوليرا و التيفوئيد والشريعة الإسلامية حرمت كل ما من شأنه أن يؤذي الإنسان.

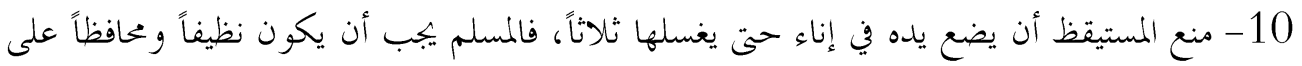
نظافة بدنه وما حوله من الأشياء.

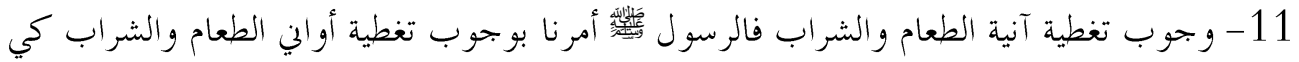
لا يصبها الفايروسات و البكتريا التي تسبب الأمر اض لإنسان.

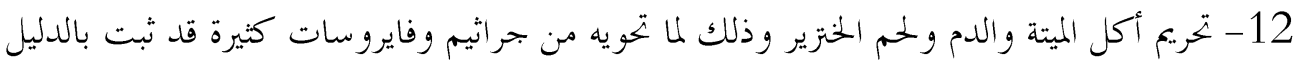
القاطع تأثريها على الإنسان. 13- تحريم الزنا، من التدابير الوقائية التي جاءت ها الشريعة الإسلامية صيانةً للأنساب وحفظاً للجهاز التناسلي من انتقال العدوى والأمراض كالإيدز وغيره. 14- منع الخروج والدخول من الأرض الموبوءة، وهو ما يطلق عليه اليوم بالحجر المناطقي، وذلك ولكيك لضمان عدم انتقال وانتشار الأمراض المعدية. 15- منع زيارة المريض للسليم والسليم للمريض، وذلك لضمان عدم انتقال الأمراض وزيادةً في المعلية انتشارها.

\section{التوصيات}

1- يجب على الإنسان المصاب بمرض انتقالي أن يتقي من نقل المرض لغيره حتى لا ينتشر المرض ويخرج عن السيطرة.

2- يجب الالتزام بتعليمات وزارة الصحة ونصائح الأطباء وعدم مخالفتها، ومن يخالفها فهو أتخ.

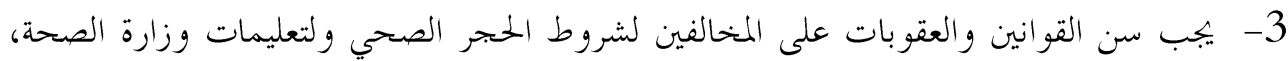

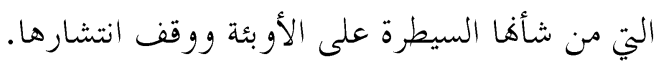


4- يجب على المريض .كرض معد عدم حضور التجمعات أو الصلاة في المساجد.

5- ضرورة تأليف لجان متخصصة من أهل العلم وذوي الخبرة، مهمتها النظر بالخصومات والقضايا

المتعلقة بالأمر اض الانتقالية في المحاكم المختصة.

6- ـ وجوب عقد المؤتمرات و الندوات التي تبين الأحكام المتعلقة بالأمراض الانتقالية، وتعريف الناس

بخطورةها و كيفية الوقاية منها وبتنبها.

ابن منظور، أبو الفضل محمد بن مكرم بن علي جمال الدين ابن منظور الأنصاري الإفريقي، لسان العرب، دار صادر - بيروت، ط/3، سنة

قلعجي، محمد رواس قلعجي - حامد صادق قنيي، معجم لغة الفقهاء، دار النفائس للطباعة والنشر والتوزيع، ط/2414، سنة 1408هـ -

1988

• ابو حماد، حسام حسن حسني، أحكام نقل الأمر اض المعدية دراسة فقهية، رسالة ماجستير في جامعة القدس - عمادة الدراسات العليا، بأشراف

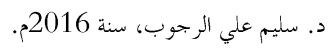

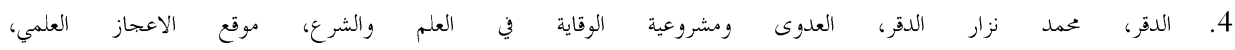

./https://draldaker.wordpress.com/2013/05/17

المرسي، ابو الحسن علي بن اسماعيل بن سيده المرسي، المحكم والمحيط الأعظم، تحقيق: عبدالحميد هنداوي، دار الكتب العمية - بيروت، سنة

المناوي، محمد عبدالرؤوف المناوي، الثوقيف على مومات التعاريف، تحقيق: د. محمد رضوان الكاية، دار الفكر - بيروت، ط/140، سنة

الفراهيدي، ابو عبد الرحمن الخليل بن أحمد الفراهيدي، العين، تحقيق: د. مهدي المخزومي و د. ابراهيم السامرائي، دار ومكتبة الهلال للطباعة

والنشر والتوزيع.

" الزبيدي، ابو الفضل محمد بن محمد بن عبدالرزاق الحسيني الزبيدي الملقب بمرتضى، تاج العروس، تعقيق: بجموعة من المحققين، دار الهداية -

• الجوزي، أبو الفرج جمال الدين بن علي بن محمد بن جعفر الجوزي، المدهش، تحقيق: د. مروان قباني، دار الكتب العلمية - بيروت، ط / 2،

سنة 1985م.

1أ.د. أحمد محمد أبو طه، التدابير الوقائية من الوقوع في جريمة العرض الفعلية، بحث منشور بكجلة كلية الشريعة والقانون، تفهنا الأشرف دقهلية،

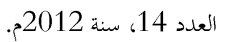

الطويلي، أحمد أحمد صالح الطويلي، التدابير الوقائية من الحربمة في الشريعة الإسلامية دراسة مقارنة، رسالة دكتوراه في جامعة صنعاء - اليمن،

سنة 2005م.

الجرجاني، علي بن محمد بن علي الزين الشريف الجرجاني، التعريفات، تحقيق: ضبطه وصححه جماعة من العلماء باشراف الناشر، دار الكتب

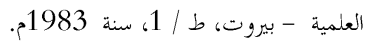

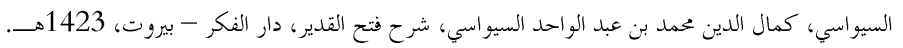

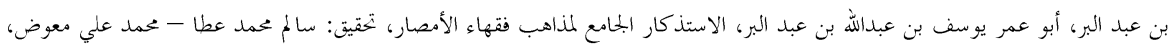
.14

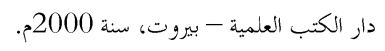
1السيوطي، جلال الدين عبد الرحمن بن أبي بكر السيوطي، الحاوي للفتاوي في الفقه، تحقيق: عبد اللطيف حسن عبد الرحمن، دار الكتب العلمية

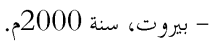

الرحيباني، مصطفى السيوطي الرحيباني، مطالب أولي النهى، المكتب الإسلامي، سنة 1961 م. 
17. الشو كاني، محمد بن علي بن محمد بن عبد الله الشو كاني اليمني، نيل الأوطار، تحقيق: عصام الدين الصبابطي، دار الحديث - مصر، ط/19 سنة

18. بن شرف، أبو زكريا محيي الدين بن شرف، المناج شرح صحيح مسلم بن اللحاج، ط / 2، دار الفكر - بيروت، سنة 1392 هـ.

$$
\begin{aligned}
& \text { ينظر : ابن منظور، لسان العرب، (231/7-233) مادة: مرض. } \\
& \text { ينظر : قلعجي، معجم لغة الفقهاء (422). } \\
& \text { ينظر: أبن منظور، لسان العرب (39/15 ) مادة: عدى. } \\
& \text { ينظر: ابو حماد، أحكام نقل الأمر اض المعدية دراسة فقهية (18). }
\end{aligned}
$$

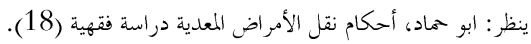

$$
\begin{aligned}
& \text { ينظر : أبن منظور، لسان العرب (39/15) مادة: عدى. العاد. }
\end{aligned}
$$

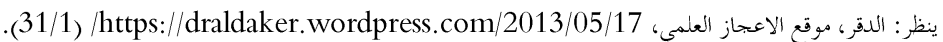

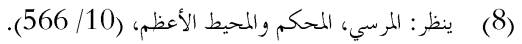

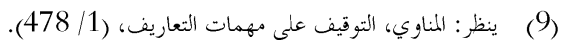

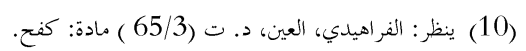

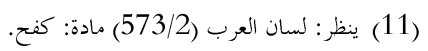

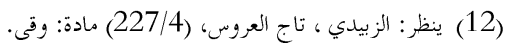

(13) ينظر : الجوزي، المدهش، (135/1) بناج العروس، (135). (14) ينظر: المصدر نفسه.

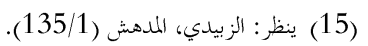

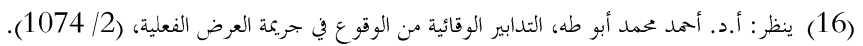

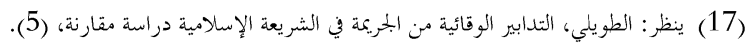

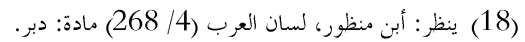

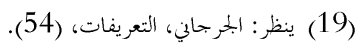

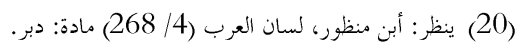

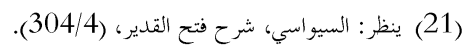

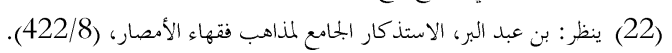

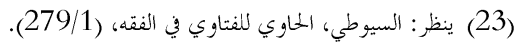

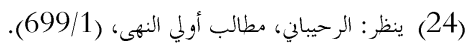

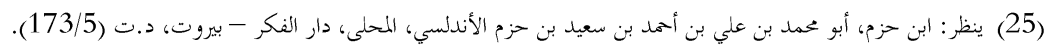

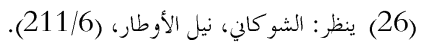

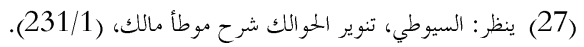

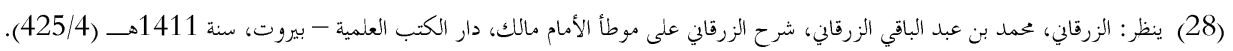

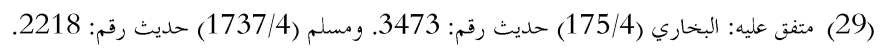

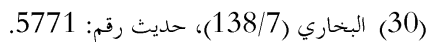

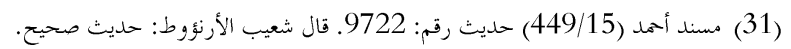

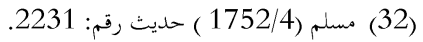

(33) البحاري (32) (130/7) ) حديث رقم: 5729.

(34) سنن ابن ماجة (1172/2) حديث رقم: 3543، في الزوائد رجال إسناده ثقات، وهو حديث حسن صحيح. 


$$
\begin{aligned}
& \text { (35) الطب النبوي (355/1) حديث رقم: 291، قال أبن حجر: حديث واه أو ضعيف. }
\end{aligned}
$$

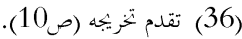

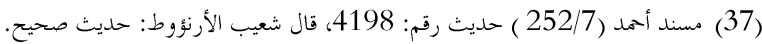

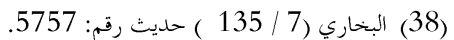

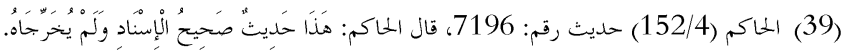

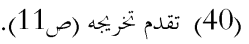

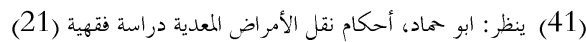

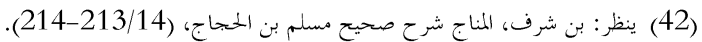

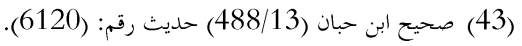

$$
\begin{aligned}
& \text { (44) الترمذي (456/4) صحيح ان حبان (456) حديث رقم: } 1817 .
\end{aligned}
$$

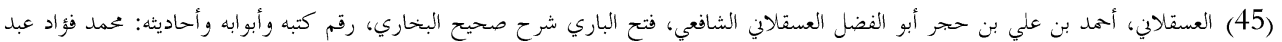

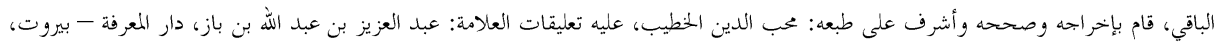

$$
\text { سنة 1379هـ (160/10). }
$$

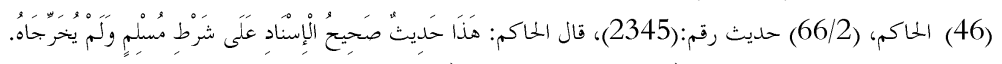

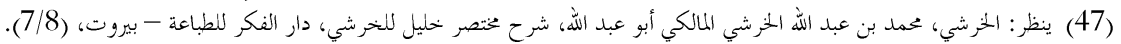

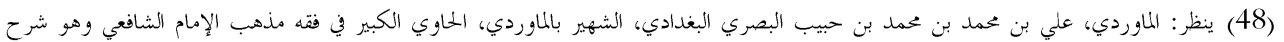

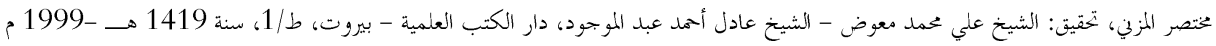

(49) ينظر: ابن قدامة، أبو محمد موفق الدين عبد اللّ بن أممد بن محمد بن قدامة الجماعيلي المقدسي ثم الدمشقي الحنبلي، المغني، مكتبة القاهرة - مصر، سنة

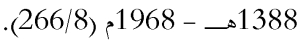

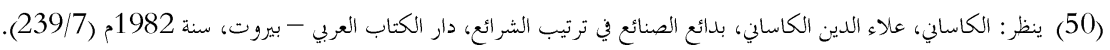

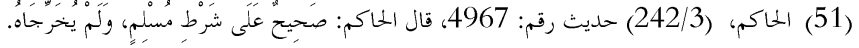

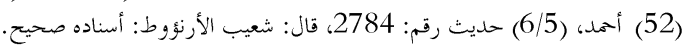

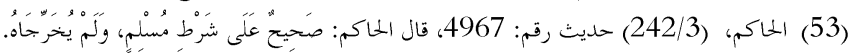

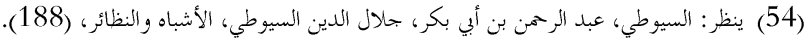

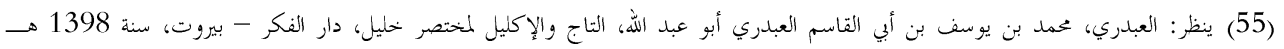
.(320/6)

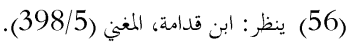

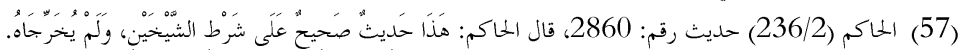

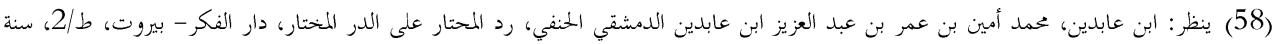

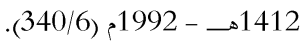

(59) ينظر : القر افي، شهاب الدين أحمد بن ادريس القر افي، الذخيرة، تحقيق: محمد حجي، دار الغرب - بيروت، سنة 1994م (258/13).

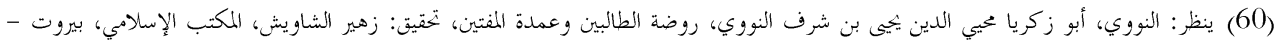

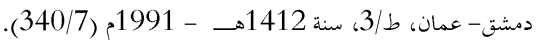

(61) ينظر: المرداوي، عاء الدين أبو الحسن علي بن سليمان المرداوي الدمشقي الصالحي الحنبلي، الإنصاف في معرفة الراجح من الحلاف، دار إحياء التراث العربي، ط/2/3، د. ت (6) (328/8).

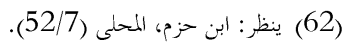

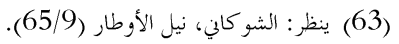

(64) ينظر: ابن عابدين، رد المحتار على الدر المختار (63) (340/6). 


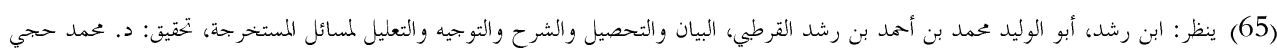

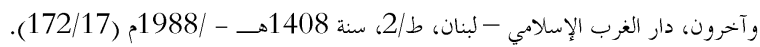

(66) ينظر: المرداوي، الإنصاف في معرفة الراجح من الخلاف (628/8) (328).

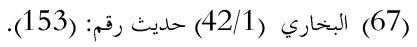

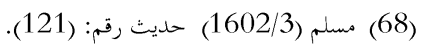

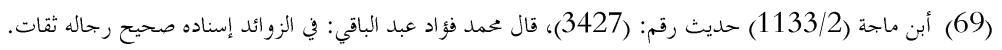

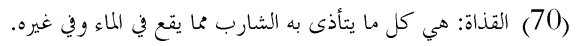

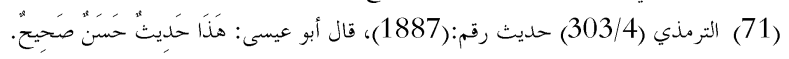

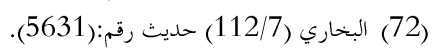

(73) ينظر: الدقر، العدوى ومشروعية الوقاية في العلم والشرع (53/1) (35/1).

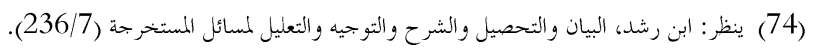

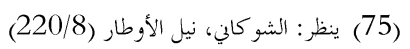

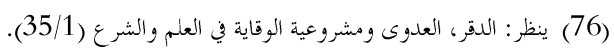

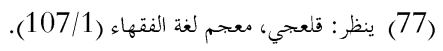

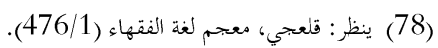

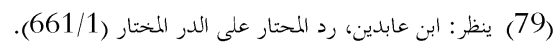

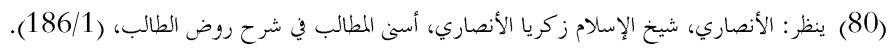

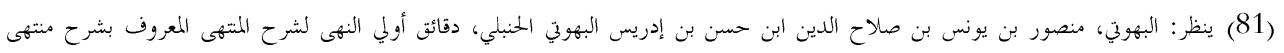

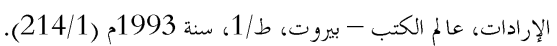

(82) ينظر: الحطاب الرٔعيني، شمس الدين أبو عبد الله محمد بن محمد بن عبد الرحمن الطرابلسي المغربي، مواهب الجليل في شرح عختصر خليل، دار الفكر -

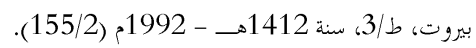
(83)

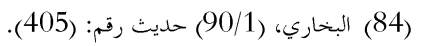

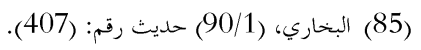

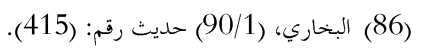

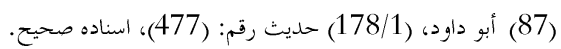

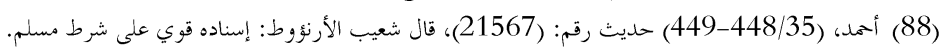
(89) البخاري، (90/1) أحما، حديث رقم: (408). (90) ينظر: الخطيب الشربيني، ششس الدين محمد بن أحمد الخطيب الشربيني الشافعي، مغني المحتاج إلى معرفة معاني ألفاظ المنهاج، دار الكتب العلمية، ط/1/، سنة 1415هـ - 1994م (83/1).

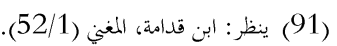

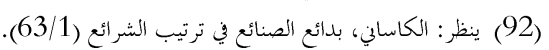

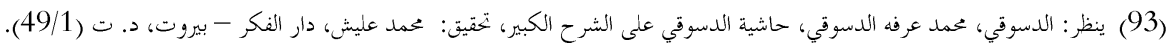

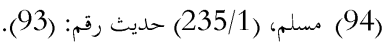

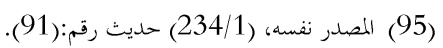

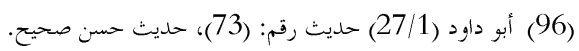

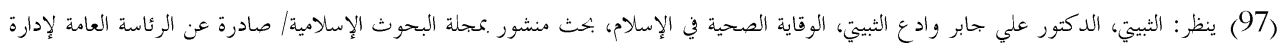

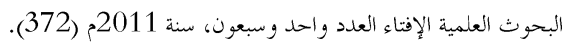

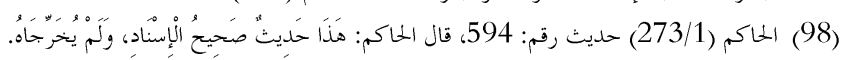




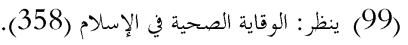

$$
\begin{aligned}
& \text { (100) (مسلم: (235/1) حديث رقم: (95). }
\end{aligned}
$$

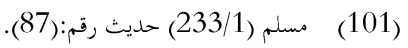

$$
\begin{aligned}
& \text { (102) مسلم، (103/3) (1596/3) حديث رقم: (99) (159/3). }
\end{aligned}
$$

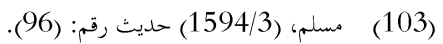

$$
\begin{aligned}
& \text { (104) أمد، (105/40-493-153/3) حديث رقم: (24433)، قال شعيب الأرنؤوط: حديث حسن لغيره. }
\end{aligned}
$$

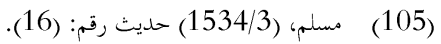

(106) ينظر:ابراهيم، د. أحمد شوقي ابراهيم، المحرمات وصحة الإنسان والطب الوقائي موسوعة المعارف الطبية في ضوء القرآن والسنة، دار الفكر العربي

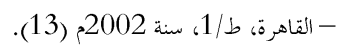

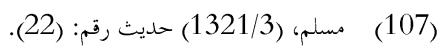

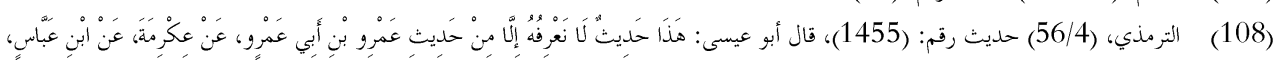

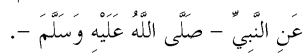

$$
\begin{aligned}
& \text { (1109) أحمد (26/5) حديث رقم: (2816)، قال شعيب الأرنؤوط: إسناده جيد، رجاله رجال الصحيح. }
\end{aligned}
$$

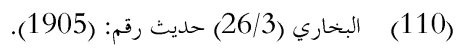$$
\text { (111) متفق عليه: البحاري: (115/4) (110) حديث رقم: (1743) (1737). ومسلم (1737/4) حديث رقم: (2218). }
$$

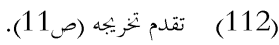

(113) ينظر: الهيتمي، أحمد بن محمد بن علي بن حجر الميتمي السعدي الأنصاري، الفتاوى الفتهية الكبرى، جمعها: الشيخ عبد القادر بن أممد بن علي

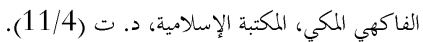

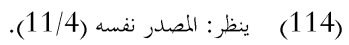

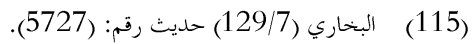$$
\text { (116) ينظر : ابو حماد، أحكام نقل الأمراض المعدية دراسة فقهية (120) (120). }
$$$$
\text { (117) يظر المصدر نفسه. }
$$$$
\text { (118) البخاري (11/2) حديث رقم: (117) (1239). }
$$$$
\text { (119) المصدر ننسه (11/2) حديث رقم: (118) (1240). }
$$

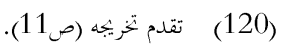

